ANL-6688

Health and Safety

(TID-4500, 19th Ed。)

AEC Research and

Development Report

ARGONNE NATIONAL LABORATORY

9700 South Cass Avenue

Argonne, Illinois

A REVIEW OF THE ARGONNE NATIONAL LABORATORY RADIATION EXPOSURE EXPERIENCE FOR THE YEARS 1959-1961

by

Pete Tedeschi

Industrial Hygiene and Safety Division

February 1963

Operated by The University of Chicago under

Contract W-31-109-eng-38

with the

U. S. Atomic Energy Commission 


\section{DISCLAIMER}

This report was prepared as an account of work sponsored by an agency of the United States Government. Neither the United States Government nor any agency Thereof, nor any of their employees, makes any warranty, express or implied, or assumes any legal liability or responsibility for the accuracy, completeness, or usefulness of any information, apparatus, product, or process disclosed, or represents that its use would not infringe privately owned rights. Reference herein to any specific commercial product, process, or service by trade name, trademark, manufacturer, or otherwise does not necessarily constitute or imply its endorsement, recommendation, or favoring by the United States Government or any agency thereof. The views and opinions of authors expressed herein do not necessarily state or reflect those of the United States Government or any agency thereof. 


\section{DISCLAIMER}

Portions of this document may be illegible in electronic image products. Images are produced from the best available original document. 
TABLE OF CONTENTS

Page

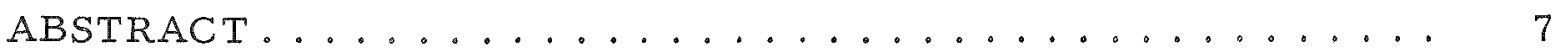

Chapters

A. INTRODUCTION. ...................... 7

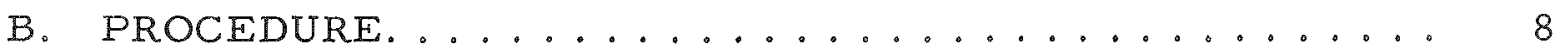

C. PRESENTATION OF DATA ................... 8

1. Tables Showing Distribution of Exposures. . . . . . . . 8

2. Graphic Presentations................... 10

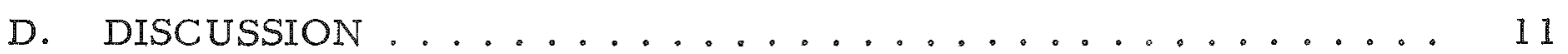

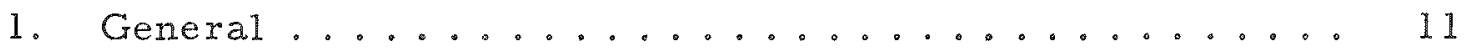

2. Age at Time of Latest Film Reading within the Year,

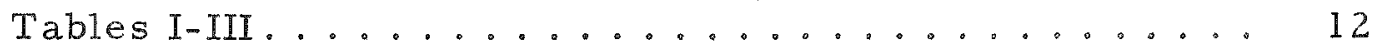

3. Years of Employment at Time of Latest Film Reading within the Year, Tables IV-VI. ............. 16

4. Laboratory Division at Time of Exposure to External Radiation, Tables VII-X............... 20

5. Job Group at Time of Exposure to External Radiation, Tables XI-XIV....................... 25

6. Sex of ANL Employees Exposed to External Radiation,

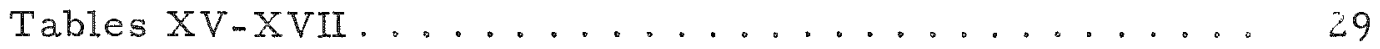

7. Distribution of Employees by Range of Exposure,

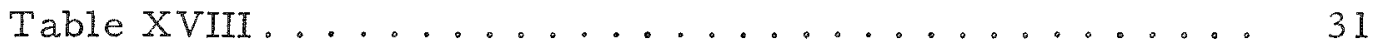

8. Evaluation of Performance - Indices of Exposure Experience, Table XIX .................... 33

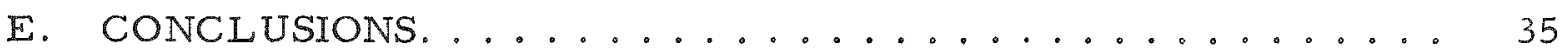

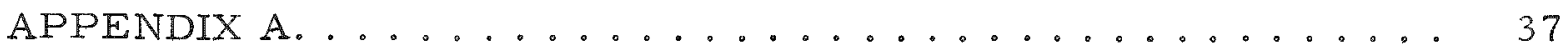

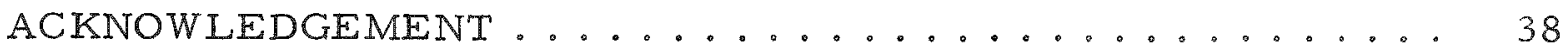




\section{LIST OF FIGURES}

No.

Title

Page

1. Age at Time of Latest Film Reading within the Year - Body Film Data - Calendar Year 1959 ..............

2. Age at Time of Latest Film Reading within the Year - Body Film Data - Calendar Year 1960 ............. 14

3. Age at Time of Latest Film Reading within the Year - Body

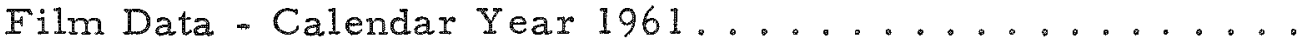

4. Years of Employment at Time of Latest Film Reading within the Year - Body Film Data - Calendar Year 1959........

5. Years of Employment at Time of Latest Film Reading within the Year - Body Film Data - Calendar Year 1960........

6. Years of Employment at Time of Latest Film Reading within the Year - Body Film Data - Calendar Year 1961........

7. Laboratory Division at Time of Exposure to External Radiation - Film Data - Calendar Year 1959...........

8. Laboratory Division at Time of Exposure to External Radiation - Film Data - Calendar Year 1960..........

9. Laboratory Division at Time of Exposure to External Radiation - Film Data - Calendar Year 1961.......... 24

10. Job Group at Time of Exposure to External Radiation - Film Data - Calendar Year 1959................

11. Job Group at Time of Exposure to External Radiation - Film

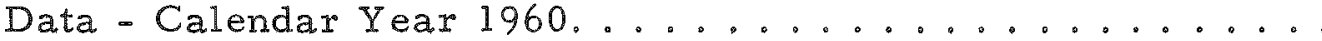

12. Job Group at Time of Exposure to External Radiation - Film Data - Calendar Year 1961..................

13. Sex of ANL Employees Exposed to External Radiation - Body

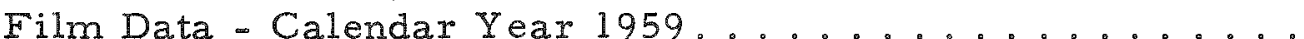

14. Sex of ANL Employees Exposed to External Radiation - Body Film Data - Calendar Year 1960 ............ 30

15. Sex of ANL Employees Exposed to External Radiation - Body

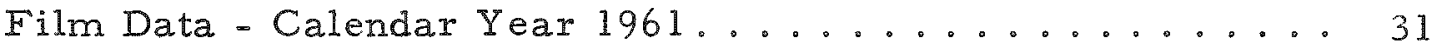

16. Distribution of Employees by Exposure $=1959 \ldots \ldots 32$

17. Distribution of Employees by Exposure - 1960........ 32 
No.

18. Distribution of Employees by Exposure - 1961. . . . . . . . 32

19. Frequency Rate - Number of Measurable Exposures per Million Manhours Worked ................. 34

20. Exposure Rate for Film with Measurable Readings Determined Quarterly for 1959 through 1961 and the First

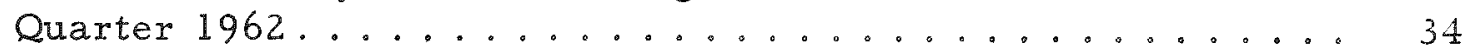

21. Average Exposure for Film with Measurable Readings Determined Quarterly for 1959 through 1961 and the First Quarter $1962 \ldots \ldots \ldots \ldots \ldots \ldots \ldots \ldots \ldots$ 


\section{LIST OF TABLES}

No.

Title

Page

I. Age at Time of Latest Film Reading within the Year - Body

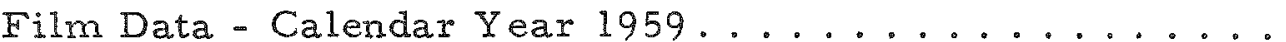

II. Age at Time of Latest Film Reading within the Year - Body Film Data - Calendar Year 1960.............. 14

III. Age at Time of Latest Film Reading within the Year - Body Film Data - Calendar Year 1961 ...............

IV. Years of Employment at Time of Latest Film Reading within the Year - Body Film Data - Calendar Year 1959. . . . . . .

V. Years of Employment at Time of Latest Film Reading within the Year - Body Film Data - Calendar Year 1960. . . . . . .

VI. Years of Employment at Time of Latest Film Reading within the Year - Body Film Data - Calendar Year 1961........

VII. Laboratory Division at Time of Exposure to External Radiation - Film Data - Calendar Year 1959.........

VIII. Laboratory Division at Time of Exposure to External Radiation - Film Data - Calendar Year 1960.........

IX. Laboratory Division at Time of Exposure to External

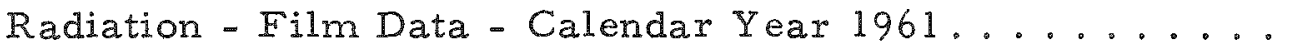

X. Rank Order of Laboratory Divisions by Number of Employees with Measurable Exposures . . . . . . . . . . . . . . . .

XI. Job Group at Time of Exposure to External Radiation - Film

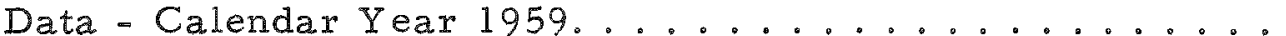

XII. Job Group at Time of Exposure to External Radiation - Film

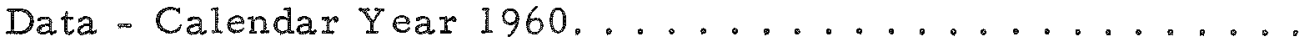

XIII. Job Group at Time of Exposure to External Radiation - Film

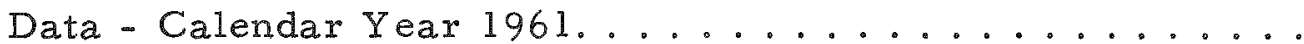

XIV. Percent of Exposure Experience Represented by Each Job Group. .........................

XV. Sex of ANL Employees Exposed to External Radiation - Body

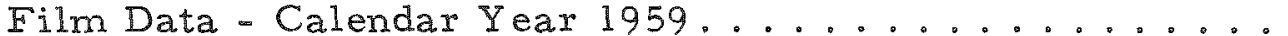

XVI. Sex of ANL Employees Exposed to External Radiation - Body Film Data - Calendar Year 1960 ............... 
No. Title

XVII. Sex of ANL Employees Exposed to External Radiation Body Film Data - Calendar Year 1961 ............ 31

XVIII. Distribution of Employees by Range or Exposure . . . . 32

XIX. Factors of Exposure Experience............... 34 


\title{
A REVIEW OF THE ARGONNE NATIONAL LABORATORY RADIATION EXPOSURE EXPERIENCE FOR THE YEARS 1959-1961
}

by

Pete Tedeschi

\begin{abstract}
A general analysis of the Argonne National Laboratory experience with radiation exposure of employees was made by means of machine-processed records. Distribution of employee exposures according to Age, Years of Employment, Laboratory Division, Job Group, and Sex were determined for a three-year period. A $23.6 \%$ increase in the number of employees monitored occurred from 1959 to 1961. The number of measurable exposures increased 107\%. The greatest influence on the increase in measurable exposure was probably due to a change to a more sensitive film and from a one-week to a iwo-week film-wearing period. Evaluation of performance using the factors Frequency Rate, Exposure Rate, and Average Exposure reveals that the Radiation Safety Program is improving in effectiveness. The exposure rate has been reduced by as much as $71.1 \%$, and the average exposure was reduced $42.4 \%$.
\end{abstract}

\section{A. INTRODUCTION}

The primary aim of any Radiation Safety Program is to minimize radiation exposure to man. When work deals primarily with radioactive materials and radiation-producing machines, this goal is not the end point but an on-going improvement of the total work situation. The aim of the Radiation Safety Program then is to improve operations. The Health Physicist tries to control the exposure of employees to radiation by controlling the hazard and/or the exposure dosage of employees. If enough "controlled situations" are allowed to exist in a non-improving situation, it would be possible for a large number of employees to receive exposure to a large amount of radiation. Because of this, it is advisable to review periodically the effectiveness of the Radiation Safety Program. A good measure of the effectiveness of a program is to determine whether there is a decrease of employee exposure. An increase in the number or degree of employee exposures to radiation would indicate the need for more effective supervisory controls or better methods of operating. 
There are a number of questions to be asked in reviewing the radiation exposure experience of a work force. Among these are:

(a) What are the ages of employees who receive radiation exposures?

(b) How much experience do they have with the company?

(c) What type of work do they do?

(d) What are their general duties and responsibilities?

(e) What is the direction taken by the Laboratory exposure trends?

This study is limited to answering the above questions.

\section{B. PROCEDURE}

The radiation-exposure data were taken from measurements made with personnel-monitoring film. The data were put onto punched cards, each of which contained the employee's identification, date of the exposure, film identification, and radiation exposure. One card was punched for each monitoring film. Each card was then visually checked for exrors against the source documents and corrected as necessary.

Master name cards were punched from employee status information supplied by the Personnel Department of the Laboratory. Each card contained the employee's identification number, effective date of the job status, name, birthdate, employment date, laboratory group code, job classification code, and sex.

The data were transferred from each deck of cards to tape by means of the IBM-1401 machine. Two tapes, one containing details of radiation-exposure data and one containing employment status information were made. The two tapes, which were written in binary coded decimal were processed through the IBM-704 and binary tapes were produced. The binary tapes were used as input tapes for the 704 program to produce the necessary reports.

\section{PRESENTATION OF DATA}

\section{Tables Showing Distribution of Exposures}

The frequency-distribution tables, such as Table I, are the printouts from the 704. The employee's status at the time of his latest film reading within a given year was used to place the employee in a class or group interval. It is possible that some employees changed groups in a given year. 
As an example, assume the following: An employee was assigned film from July 1959 to July 1960. From July through December 1959 he was in the Idaho Division; in January 1960 he joined Industrial Hygiene and Safety, and in July 1960 he transferred to Reactor Operations. At time of latest exposure (given in Table VII), he would be counted as being in the Idaho Division on December 31, 1959. In 1960 he would be counted in Reactor Operations, which is the class interval into which he belonged at the time of his latest film reading on July 31, 1960. A small error is incurred by counting the employee only in the group interval that he was in at the time of his last film reading in the year.

The Expected frequencies under the major column heading No. of Employees Assigned Film in Tables I-IX, XI-XIII, and XV-XVII are calculated frequencies. They were determined on the basis that the number of employees assigned film is distributed in the same proportion as the total laboratory population for each class interval. The Expected values were calculated as

No. of Laboratory Employees

Total No. of Employees

Assigned Film $\mathrm{x} \frac{\text { in Each Class Interval }}{\text { Total Laboratory Population }}$.

The Actual frequencies are the observed frequencies.

Similarily, the Expected number of employees with measurable exposures were calculated by means of the relationship

Actual No. of Employees Assigned

Total No. of Employees with Measurable Exposures

$\mathrm{Film}$ in Each Class Interval

Total Number of Employees

Assigned Film

A chi-square test revealed that the actual frequencies of employees assigned film was not proportional to the frequencies of the total Laboratory population. Also, the frequency distribution of the actual number of employees with measurable exposures was not proportional to the frequency distribution of the number of films assigned with the exception of the distributions in Tables II, III, and V. The Expected and Actual frequencies of employees with measurable readings in Tables II, III, and V show an insignificant difference. The difference was considered insignificant if there was a probability of 0.05 or greater that the calculated distribution would describe the actual distribution.

The term MPL in the last two columns of the distribution Tables IIX, XI-XIII, and XV-XVII refers to weekly maximum permissible levels. The MPL for 1959 through June 1960 was $300 \mathrm{mrem} /$ week. From July 1960 through 1961 , the MPL was $300 \mathrm{mrem} / 2$ weeks. If, during any film-wearing 
period in the year, an employee's film exposure exceeded the maximum permissible level, he was counted in the next-to-the-last column. The employee was counted only once in the year. Each time a film reading exceeded the permissible level it was counted in the last column on the right. The last column shows that some employees exceeded the weekly MPL more than once. These two columns will reveal class or group intervals that may be receiving relatively large or small amounts of radiation exposures.

Table XVIII shows the distribution of employees by range of exposures. The distribution is also expressed in accumulated percent to show the exposure level below which most of the exposures occur. The distribution of employees is based upon the employee's accumulated radiation exposure for the given year.

Table XIX guves the values for the indices of exposure experience that are used in evaluating the effectiveness of Radiation Safety Program (1) The indices were determined as follows:

Frequency Rate $=(\mathrm{N} / \mathrm{M}) \times 10^{6}=$ Number of Exposed Film $/ 10^{6}$ Manhours.

Exposure Rate $=\Sigma \mathrm{r} / \mathrm{NH}=\mathrm{mr} / \mathrm{hr}$.

Average Exposure $=\Sigma r / N=$ Average exposure in milliroentgens as recorded on the films.

where $\mathrm{N}=$ Number of films with a measurable reading of $25 \mathrm{mr}$ or greater.

$M=$ Total manhours worked by all employees for the stated period based upon the Accounting Department's figures of paid manhours with absence manhouxs deducted.

$r=$ The readings in milliroentgens on each film with a measurable reading of $25 \mathrm{mr}$ or greater.

$\mathrm{H}=$ The number of hours that each film with a meas urable reading was worn.

Some employees wore several films in a given monitoring period. The average exposure is a film average. It closely approximates the employee averages since approximately $95 \%$ of the employees wear one film during a given monitoring period. Only $0.6 \%$ of the employees wear more than two films in a monitoring period and these employees wear three films.

2 Graphic Presentations

The frequency polygons, such as in Figs. 1-6, are presentation of the data in Tables I-VI. The uppermost curve in each figure represents the distribution for all the Laboratory employees. The middle curve 
represents the distribution for employees who were assigned monitoring film. The bottom curve is the distribution for employees who received measurable exposures. By taking the difference between the top curve and the middle curve one gets the distribution for employees not assigned film. By taking the difference between the middle curve and bottom curve, one gets the distribution for employees assigned film but receiving no measurable exposures.

Figures $7-15$ are histograms representing the data in Tables VIIIX, XI-XIII, and XV-XVII. In the same manner as was described for the frequency polygon, one can take the difference between the overlapping histograms and determine the distribution for employees not assigned film and the number of employees assigned film but receiving no measurable exposures.

The curves in Figs. 16-18 represent the cumulative distribution of the data from Table XVIII. The data have been accumulated on a "less than" basis; thus, the curve shows the number of persons who received less than the stated exposures.

The data for the Indices of Exposure Experience are plotted in Figs. 19-21. Trend lines have been fitted to each curve using the high-low mid-point method. The trend lines give a better picture of a resultant direction of the cyclic movements described by the curves.

\section{DISCUSSION}

\section{General}

The employees at the Laboratory are monitored on an "as needed" basis. As a result, a little less than half of the employees are assigned personal monitoring devices. In 1961 , for instance, 2317 or $45.5 \%$ of the Laboratory employees were monitored. Of these, 1182 or $51.0 \%$ received measurable exposures. A measurable exposure is one that measures $25 \mathrm{mr}$ or more. Tables I through III show that from 1959 to 1961 the increase in the number of employees with measurable readings is greater than the increase in the number monitored. The explanation for the greater increase in employees with measurable readings is that the Laboratory changed to a more sensitive monitoring film and extended the wearing period from one week to two weeks in July 1960. Thus, many employees whose exposure measurements formerly were slightly below the threshold of detection began to show measurable exposures. 
2. Age at Time of Latest Film Reading within the Year, Tables I-III

The mean ages (plus or minus one standard deviation) shown below indicate that the distribution of the ages of employees assigned film and of those receiving measurable exposures are similar. The slight differences are considered as fluctuations due to chance.

\begin{tabular}{|c|c|c|c|c|}
\hline \multirow{4}{*}{ Year } & \multicolumn{4}{|c|}{ MEAN AGE IN YEARS PLUS OR } \\
\cline { 2 - 5 } & $\begin{array}{c}\text { MINUS ONE STANDARD DEVIATION } \\
\text { Employees }\end{array}$ & $\begin{array}{c}\text { Employees } \\
\text { As } \\
\text { Figned }\end{array}$ & $\begin{array}{c}\text { Employees } \\
\text { with Measurable } \\
\text { Exposure }\end{array}$ & $\begin{array}{c}\text { Employees } \\
\text { with Exposures } \\
\geq \text { Weekly MPL }\end{array}$ \\
\hline 1959 & $35.77 \pm 10.68$ & $36.33 \pm 9.63$ & $35.18 \pm 9.63$ & $35.55 \pm 8.16$ \\
1960 & $35.73 \pm 10.68$ & $35.95 \pm 9.80$ & $35.58 \pm 9.49$ & $34.34 \pm 8.61$ \\
1961 & $35.73 \pm 10.89$ & $36.27 \pm 9.84$ & $35.61 \pm 9.39$ & $33.94 \pm 9.40$ \\
\hline
\end{tabular}

(The standard deviation from the mean is only approximate since the distribution has a moderately positive skew as shown in Figs.1-3.)

The average age over the 3 -year period is $35.5 \pm 9.5$ years. Using the above figures for employees with measurable exposures, one can infer that $95.45 \%$ of the employees that receive measurable exposures are between the ages of 17.5 and 55.5 . 
Table I

CALENDAR YEAR 1950

AGE AT TIME OF LATEST FILM READING WITHIN THE YEAR - BODY FILM DATA

\begin{tabular}{|c|c|c|c|c|c|c|c|c|c|}
\hline \multirow[t]{2}{*}{ Range in Years } & \multirow{2}{*}{$\begin{array}{c}\text { No. of } \\
\text { Employees }\end{array}$} & \multicolumn{2}{|c|}{$\begin{array}{l}\text { No. of Enployees } \\
\text { Assigned Films }\end{array}$} & \multirow{2}{*}{$\begin{array}{l}\text { No. of Films } \\
\text { Assigned }\end{array}$} & \multicolumn{2}{|c|}{$\begin{array}{c}\text { No. of Employees } \\
\text { with Measurable } \\
\text { Exposures }\end{array}$} & \multirow{2}{*}{$\begin{array}{l}\text { No. of Films } \\
\text { with Measurable } \\
\text { Readings }\end{array}$} & \multirow{2}{*}{$\begin{array}{l}\text { No. of Employees } \\
\text { Exposed, Equal or } \\
\text { Greater MPL }\end{array}$} & \multirow{2}{*}{$\begin{array}{l}\text { No. of Films, } \\
\text { Equal or } \\
\text { Greater MPL }\end{array}$} \\
\hline & & Expected $^{2}$ & Actual & & Expected" & Actual & & & \\
\hline-16 & 0 & 0 & 0 & 0 & 0 & 0 & 0 & 0 & 0 \\
\hline $17-20$ & 92 & 40 & 15 & 205 & 5 & 1 & 2 & 0 & 0 \\
\hline $20-23$ & 411 & 180 & 116 & 2813 & 35 & 37 & 177 & 2 & 3 \\
\hline $23-26$ & 339 & 148 & 141 & 5008 & 43 & 47 & 242 & 5 & 5 \\
\hline $26-29$ & 409 & 179 & 187 & 8121 & 57 & 70 & 402 & 7 & 36 \\
\hline $29-32$ & 422 & 185 & 197 & 8346 & 60 & 68 & 397 & 14 & 17 \\
\hline $32-35$ & 482 & 211 & 231 & 10617 & 70 & 76 & 615 & 15 & 28 \\
\hline $35-38$ & 450 & 197 & 236 & 10311 & 72 & 74 & 468 & 7 & 11 \\
\hline $38-41$ & 432 & 189 & 219 & 9758 & 67 & 65 & 376 & 9 & 14 \\
\hline $41-44$ & 364 & 159 & 173 & 7697 & 53 & 45 & 264 & 7 & 15 \\
\hline $44-47$ & 242 & 106 & 108 & 4633 & 33 & 35 & 235 & 4 & 10 \\
\hline $47-50$ & 185 & 81 & 68 & 2814 & 21 & 16 & 69 & 2 & 3 \\
\hline $50-53$ & 153 & 67 & 67 & 2972 & 20 & 16 & 39 & 1 & 2 \\
\hline $53-56$ & 102 & 45 & 36 & 1548 & II & 7 & 13 & 0 & 0 \\
\hline $56-59$ & 78 & 34 & 32 & 1612 & 10 & 5 & 12 & 1 & 1 \\
\hline $59-62$ & 70 & 31 & 30 & 1496 & 9 & 4 & 27 & 2 & 2 \\
\hline $62-65$ & 38 & 17 & 14 & 587 & 4 & 4 & 18 & 0 & 0 \\
\hline $65-$ & 10 & 4 & 4 & 60 & 1 & 1 & 1 & 0 & 0 \\
\hline Total & 4279 & 1873 & 1874 & 78598 & 571 & 571 & 3357 & 76 & 127 \\
\hline
\end{tabular}

' Expected on the basis of distributing the number of film proportionally to the Age distribution.

- Expected on the basis of distributing the No. of Employees with Measurable Readings proportionally to the distribution of No. of Employees Assigned Films.

Figure 1

CALENDAR YEAR 1959

AGE AT TIME OF LATEST FILM READING

WITHIN THE YEAR - BODY FILM DATA

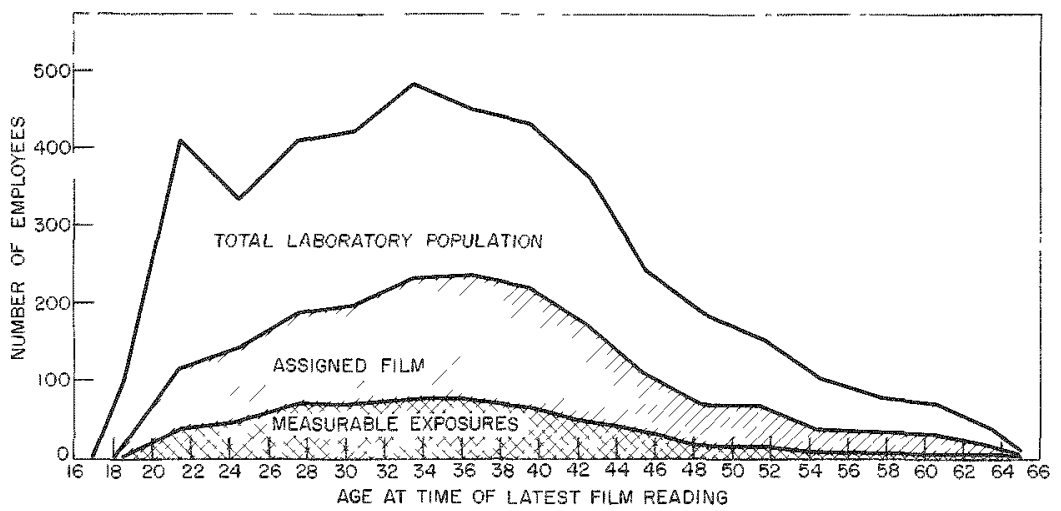


Table II

CALENDAR YEAR 1960

AGE AT TIME OF LATEST FILM READING WITHIN THE YEAR - BODY FILM DATA

\begin{tabular}{|c|c|c|c|c|c|c|c|c|c|}
\hline \multirow[t]{2}{*}{ Range in Years } & \multirow{2}{*}{$\begin{array}{c}\text { No. of } \\
\text { Employees }\end{array}$} & \multicolumn{2}{|c|}{$\begin{array}{l}\text { No. of Employees } \\
\text { Assigned Films }\end{array}$} & \multirow{2}{*}{$\begin{array}{l}\text { No. of Films } \\
\text { Assigned }\end{array}$} & \multicolumn{2}{|c|}{$\begin{array}{c}\text { No. of Employees } \\
\text { with Measurable } \\
\text { Exposures }\end{array}$} & \multirow{2}{*}{$\begin{array}{l}\text { No. of Films } \\
\text { with Measurable } \\
\text { Readings }\end{array}$} & \multirow{2}{*}{$\begin{array}{l}\text { No. of Employees } \\
\text { Exposed, Equal or } \\
\text { Greater MPL }\end{array}$} & \multirow{2}{*}{$\begin{array}{l}\text { No. of Films, } \\
\text { Equal or } \\
\text { Greater MPL }\end{array}$} \\
\hline & & Expected" & Actual & & Expected:* & Actual & & & \\
\hline $\begin{array}{l}-16 \\
17-20 \\
20-23 \\
23-26 \\
26-29 \\
29-32 \\
32-35 \\
35-38 \\
38-41 \\
41-44 \\
44-47 \\
47-50 \\
50-53 \\
53-56 \\
56-59 \\
59-62 \\
62-65 \\
65-\end{array}$ & $\begin{array}{r}0 \\
159 \\
452 \\
388 \\
434 \\
458 \\
442 \\
490 \\
477 \\
400 \\
305 \\
196 \\
171 \\
118 \\
78 \\
75 \\
51 \\
16\end{array}$ & $\begin{array}{r}0 \\
71 \\
203 \\
174 \\
195 \\
206 \\
199 \\
220 \\
214 \\
180 \\
137 \\
88 \\
77 \\
53 \\
35 \\
34 \\
23 \\
7\end{array}$ & $\begin{array}{r}0 \\
21 \\
165 \\
177 \\
223 \\
215 \\
220 \\
254 \\
236 \\
187 \\
136 \\
79 \\
77 \\
47 \\
27 \\
33 \\
16 \\
3\end{array}$ & $\begin{array}{r}0 \\
301 \\
2615 \\
4397 \\
7214 \\
7202 \\
7340 \\
8310 \\
8226 \\
6319 \\
4297 \\
2449 \\
2249 \\
1646 \\
884 \\
1232 \\
674 \\
108\end{array}$ & $\begin{array}{r}0 \\
10 \\
77 \\
83 \\
105 \\
101 \\
103 \\
119 \\
111 \\
88 \\
64 \\
37 \\
36 \\
22 \\
13 \\
15 \\
8 \\
1\end{array}$ & $\begin{array}{r}0 \\
7 \\
72 \\
75 \\
125 \\
106 \\
110 \\
130 \\
114 \\
81 \\
57 \\
30 \\
34 \\
16 \\
14 \\
11 \\
9 \\
1\end{array}$ & $\begin{array}{r}0 \\
30 \\
301 \\
404 \\
526 \\
575 \\
639 \\
592 \\
476 \\
295 \\
301 \\
128 \\
81 \\
21 \\
36 \\
43 \\
25 \\
1\end{array}$ & $\begin{array}{l}0 \\
1 \\
4 \\
8 \\
3 \\
8 \\
9 \\
9 \\
8 \\
3 \\
3 \\
2 \\
2 \\
0 \\
0 \\
1 \\
0 \\
0\end{array}$ & $\begin{array}{r}0 \\
1 \\
7 \\
10 \\
3 \\
13 \\
19 \\
23 \\
11 \\
4 \\
7 \\
3 \\
5 \\
0 \\
0 \\
2 \\
0 \\
0\end{array}$ \\
\hline Total & 4710 & 2116 & 2116 & 65463 & 993 & 992 & 4474 & 61 & 108 \\
\hline
\end{tabular}

"Expected on the basis of distributing the number of fllm proportionally to the Age distribution.

"Expected on the basis of distributing the No. of Employees with Measurable Readings proportionally to the distribution of No. of Employees Assigned Films.

Figure 2

CALENDAR YEAR 1960

\section{AGE AT TIME OF LATEST FILM READING WITHIN THE YEAR - BODY FILM DATA}

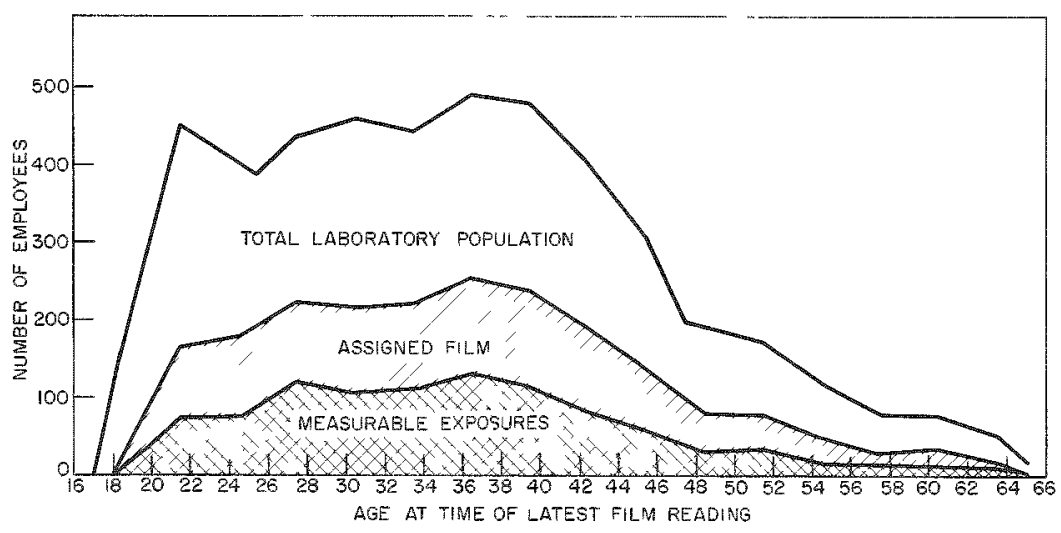


Table III

CALENDAR YEAR 1961

AGE AT TIME OF LATEST FILM READING WITHIN THE YEAR - BODY FILM DATA

\begin{tabular}{|c|c|c|c|c|c|c|c|c|c|}
\hline \multirow[t]{2}{*}{ Range in Vears } & \multirow{2}{*}{$\begin{array}{c}\text { No. of } \\
\text { Employees }\end{array}$} & \multicolumn{2}{|c|}{$\begin{array}{l}\text { No. of Employees } \\
\text { Assigned Films }\end{array}$} & \multirow{2}{*}{$\begin{array}{l}\text { No. of Films } \\
\text { Assigned }\end{array}$} & \multicolumn{2}{|c|}{$\begin{array}{c}\text { No. of Employees } \\
\text { with Measurable } \\
\text { Exposures }\end{array}$} & \multirow{2}{*}{$\begin{array}{l}\text { No. of Films } \\
\text { with heasurable } \\
\text { Readings }\end{array}$} & \multirow{2}{*}{$\begin{array}{l}\text { No. of Employees } \\
\text { Exposed, Equal or } \\
\text { Greater MPL }\end{array}$} & \multirow{2}{*}{$\begin{array}{l}\text { No. of Fillms, } \\
\text { Equal or } \\
\text { Greater MPL }\end{array}$} \\
\hline & & Expected : & Actual & & Expected": & Actual & & & \\
\hline $\begin{array}{l}-16 \\
17-20 \\
20-23 \\
23-26 \\
26-29 \\
29-32 \\
32-35 \\
35-38 \\
38-41 \\
41-44 \\
44-47 \\
47-50 \\
50-53 \\
53-56 \\
56-59 \\
59-62 \\
62-65 \\
65-\end{array}$ & $\begin{array}{r}0 \\
195 \\
499 \\
440 \\
442 \\
496 \\
444 \\
499 \\
499 \\
429 \\
371 \\
215 \\
185 \\
133 \\
87 \\
74 \\
59 \\
22 \\
\end{array}$ & $\begin{array}{r}0 \\
89 \\
227 \\
200 \\
201 \\
226 \\
202 \\
227 \\
227 \\
195 \\
169 \\
98 \\
84 \\
61 \\
40 \\
34 \\
27 \\
10\end{array}$ & $\begin{array}{r}0 \\
20 \\
169 \\
177 \\
246 \\
252 \\
228 \\
259 \\
262 \\
216 \\
184 \\
83 \\
77 \\
59 \\
26 \\
32 \\
23 \\
4\end{array}$ & $\begin{array}{r}0 \\
226 \\
2508 \\
3419 \\
5515 \\
5753 \\
5445 \\
6134 \\
6211 \\
5039 \\
3947 \\
1707 \\
1642 \\
1314 \\
590 \\
816 \\
586 \\
51\end{array}$ & $\begin{array}{r}0 \\
10 \\
86 \\
90 \\
125 \\
129 \\
116 \\
132 \\
134 \\
110 \\
94 \\
42 \\
39 \\
30 \\
13 \\
16 \\
12 \\
2\end{array}$ & $\begin{array}{r}0 \\
7 \\
80 \\
89 \\
149 \\
135 \\
135 \\
152 \\
125 \\
110 \\
65 \\
36 \\
35 \\
30 \\
7 \\
15 \\
11 \\
1\end{array}$ & $\begin{array}{r}0 \\
12 \\
368 \\
615 \\
673 \\
522 \\
613 \\
690 \\
524 \\
371 \\
314 \\
129 \\
114 \\
63 \\
32 \\
30 \\
50 \\
2\end{array}$ & $\begin{array}{r}0 \\
0 \\
7 \\
19 \\
9 \\
7 \\
7 \\
17 \\
6 \\
5 \\
8 \\
2 \\
2 \\
0 \\
1 \\
1 \\
1 \\
0\end{array}$ & $\begin{array}{r}0 \\
0 \\
24 \\
36 \\
16 \\
9 \\
17 \\
33 \\
18 \\
6 \\
12 \\
4 \\
2 \\
0 \\
1 \\
1 \\
1 \\
0\end{array}$ \\
\hline Total & 5089 & 2317 & 2317 & 50903 & 1180 & 1182 & 5122 & 92 & 180 \\
\hline
\end{tabular}

"Expected on the basis of distributing the number of film proportionally to the Age distribution.

"Expected on the basis of distributing the No. of Employees with Measurable Readings proportionally to the distribution of No. of Employees Assigned Films.

Figure 3

CALENDAR YEAR 1961

AGE AT TIME OF LATEST FILM READING WITHIN THE YEAR - BODY FILM DATA

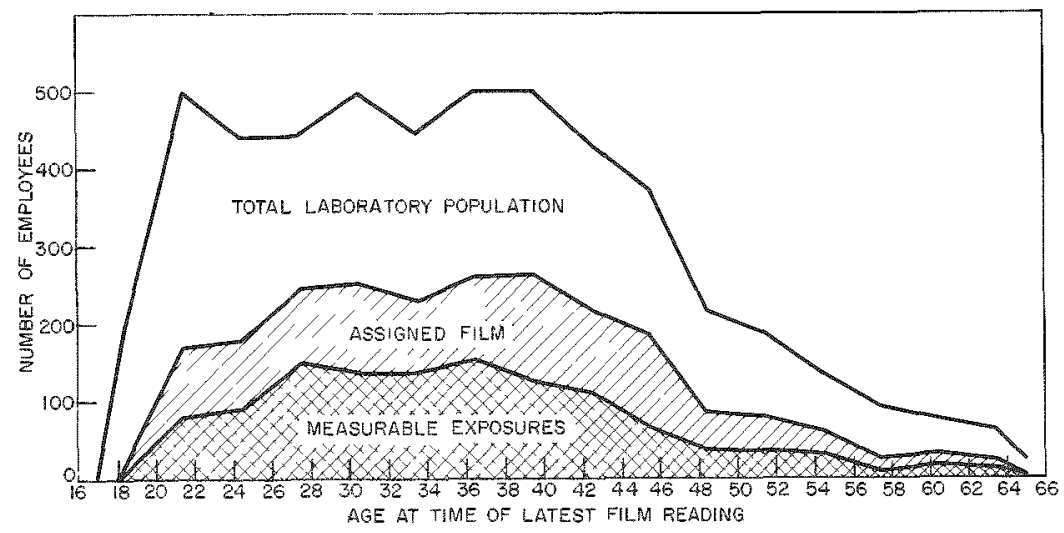


3. Years of Employment at Time of Latest Film Reading within the Year, Tables IV-VI

The shapes of the distribution curves for employees by years of employment have remained about the same for 1959, 1960, and 1961. Figures 4-6 show that after the first few years the high and low points move to the right one year with each succeeding year. The means and the medians of the overall distributions differ by only a few tenths of a year. The means and medians for each year were calculated to be as follows:

\begin{tabular}{|c|c|c|c|c|c|c|}
\hline \multirow{2}{*}{ Year } & \multicolumn{6}{|c|}{ YEARS OF EMPLOYMENT } \\
\cline { 2 - 7 } & \multicolumn{2}{|c|}{ All Employees } & \multicolumn{2}{c|}{$\begin{array}{c}\text { Employees } \\
\text { Assigned } \\
\text { Film }\end{array}$} & \multicolumn{2}{c|}{$\begin{array}{c}\text { Measurable } \\
\text { Exposures }\end{array}$} \\
\cline { 2 - 7 } & Mean & Median & Mean & Median & Mean & Median \\
\hline 1959 & 5.32 & 3.79 & 5.88 & 4.28 & 5.37 & 3.62 \\
1960 & 5.54 & 3.54 & 5.84 & 4.04 & 5.62 & 4.02 \\
1961 & 5.42 & 3.81 & 6.16 & 4.50 & 5.85 & 4.43 \\
\hline
\end{tabular}

The medians show that one-half of the employees were at the Laboratory less than four years. One-half of the employees assigned film were at the Laboratory 4.5 years or less, and one-half the employees receiving measurable exposures were at the Laboratory less than 4.5 years. In addition, $41 \%$ of the employees who exceeded the weekly maximum permissible level in 1959 and 1960 were employed 4.5 years or less. In 1961 , $52 \%$ of the employees who exceeded weekly MPL had 4.5 years or less experience at the Laboratory. 
Table IV

CALENDAR YEAR 1959

YEARS OF EMPLOYMENT AT TIME OF LATEST FILM READING WITHIN THE YEAR - BODY FILM DATA

\begin{tabular}{|c|c|c|c|c|c|c|c|c|c|}
\hline \multirow[t]{2}{*}{ Range in Years } & \multirow{2}{*}{$\begin{array}{l}\text { No. of } \\
\text { Employees }\end{array}$} & \multicolumn{2}{|c|}{$\begin{array}{l}\text { No. of Employees } \\
\text { Assigned Films }\end{array}$} & \multirow{2}{*}{$\begin{array}{l}\text { No. of Films } \\
\text { Assigned }\end{array}$} & \multicolumn{2}{|c|}{$\begin{array}{c}\text { No. of Employees } \\
\text { with Measurable } \\
\text { Exposures }\end{array}$} & \multirow{2}{*}{$\begin{array}{l}\text { No. of Films } \\
\text { with Measurable } \\
\text { Readings }\end{array}$} & \multirow{2}{*}{$\begin{array}{l}\text { No. of Employees } \\
\text { Exposed, Equal or } \\
\text { Greater MPL }\end{array}$} & \multirow{2}{*}{$\begin{array}{l}\text { No. of Films, } \\
\text { Equal or } \\
\text { Greater MPL }\end{array}$} \\
\hline & & Expected & Actual & & Expected ${ }^{3}$ & Actual & & & \\
\hline-.5 & 612 & 268 & 173 & 2136 & 53 & 43 & 111 & 0 & 0 \\
\hline $.5-1.5$ & 603 & 264 & 218 & 7611 & 66 & 76 & 288 & 8 & 13 \\
\hline $1.5-2.5$ & 530 & 232 & 232 & 9530 & 71 & 73 & 450 & 7 & 13 \\
\hline $2.5-3.5$ & 469 & 205 & 238 & 11366 & 73 & 88 & 566 & 11 & 18 \\
\hline $3.5-4.5$ & 217 & 95 & 92 & 4109 & 28 & 33 & 249 & 5 & 7 \\
\hline $4.5-5.5$ & 159 & 70 & 80 & 3800 & 24 & 25 & 85 & 0 & 0 \\
\hline $5.5-6.5$ & 104 & 46 & 61 & 3362 & 19 & 26 & 122 & 5 & 8 \\
\hline $6.5-7.5$ & 121 & 53 & 54 & 2615 & 16 & 23 & 183 & 6 & 10 \\
\hline $7.5-8.5$ & 194 & 85 & 96 & 4486 & 29 & 41 & 403 & 5 & 9 \\
\hline $8.5-9.5$ & 232 & 102 & 115 & 5682 & 35 & 26 & 181 & 4 & 5 \\
\hline $9.5-10.5$ & 214 & 94 & 112 & 4913 & 34 & 22 & 131 & 5 & 9 \\
\hline $10.5-11.5$ & 240 & 105 & 128 & 6252 & 39 & 26 & 145 & 7 & 9 \\
\hline $11.5-12.5$ & 181 & 79 & 88 & 3706 & 27 & 19 & 155 & 3 & 6 \\
\hline $12.5-13.5$ & 139 & 61 & 73 & 3812 & 22 & 26 & 173 & 5 & 12 \\
\hline $13.5-14.5$ & 86 & 38 & 38 & 1846 & 12 & 10 & 46 & 2 & 2 \\
\hline $14.5-15.5$ & 61 & 27 & 28 & 1164 & 9 & 4 & 8 & l & 2 \\
\hline $15.5-16.5$ & 81 & 35 & 29 & 1285 & 9 & 6 & 13 & 2 & 4 \\
\hline $16.5-17.5$ & 27 & 12 & 16 & 810 & 5 & 4 & 48 & 0 & 0 \\
\hline $17.5-18.5$ & 9 & 4 & 3 & 113 & 1 & 0 & 0 & 0 & 0 \\
\hline $18.5-$ & 0 & 0 & 0 & 0 & 0 & 0 & 0 & 0 & 0 \\
\hline Total & 4279 & 1875 & 1874 & 78598 & 572 & 571 & 3357 & 76 & 127 \\
\hline
\end{tabular}

-Expected on the basis of distributing the number of film proportionally to the Years of Employment distribution.

- Expected on the basis of distributing the No. of Employees with Measurable Readings proporionally to the distribution of No. of Employees Assigned Films.

Figure 4

CALENDAR YEAR 1959

\section{YEARS OF EMPLOYMENT AT TIME OF \\ LATEST FILM READING WITHIN THE YEAR - BODY FILM DATA}

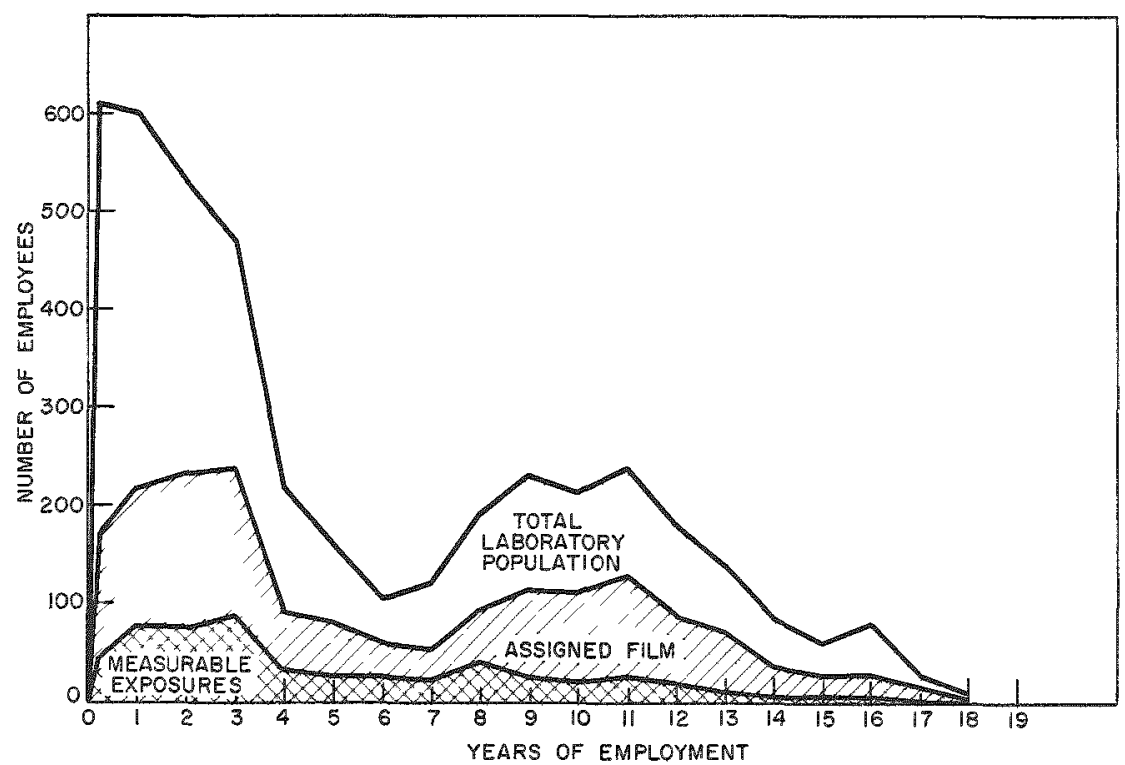


Table $\mathrm{Z}$

CALENDAR YEAR 1960

YEARS OF EMPLOYMENT AT TIME OF LATEST FILM READING WITHIN THE YEAR - BODY FILM DATA

\begin{tabular}{|c|c|c|c|c|c|c|c|c|c|}
\hline \multirow[t]{2}{*}{ Range in Years } & \multirow{2}{*}{$\begin{array}{c}\text { No. of } \\
\text { Employees }\end{array}$} & \multicolumn{2}{|c|}{$\begin{array}{l}\text { No. of Enoloyees } \\
\text { Assigned Films }\end{array}$} & \multirow{2}{*}{$\begin{array}{l}\text { Ao. of Films } \\
\text { Assigned }\end{array}$} & \multicolumn{2}{|c|}{$\begin{array}{c}\text { Wo. of Employess } \\
\text { with Measurable } \\
\text { Exposures }\end{array}$} & \multirow{2}{*}{$\begin{array}{c}\text { No. of Films } \\
\text { with Measurable } \\
\text { Readings }\end{array}$} & \multirow{2}{*}{$\begin{array}{l}\text { No. of Employees } \\
\text { Exposed, Equal or } \\
\text { Greater MPL }\end{array}$} & \multirow{2}{*}{$\begin{array}{l}\text { No. of Flims, } \\
\text { Equal or } \\
\text { Greater MPL }\end{array}$} \\
\hline & & Expected & Actual & & Expected ${ }^{2}$ & Actual & & & \\
\hline-5 & 539 & 242 & 188 & 1699 & 88 & 69 & 176 & 3 & 3 \\
\hline $.5-1.5$ & 866 & 389 & 341 & 7793 & 160 & 169 & 877 & 8 & 10 \\
\hline $1.5-2.5$ & 459 & 206 & 197 & 6265 & 92 & 91 & 323 & 4 & 6 \\
\hline $2.5-3.5$ & 448 & 201 & 196 & 6696 & 92 & 99 & 493 & 4 & 9 \\
\hline $3.5-4.5$ & 420 & 189 & 228 & 8335 & 107 & 119 & 542 & 6 & 11 \\
\hline $4.5-5.5$ & 199 & 89 & 83 & 2956 & 39 & 45 & 212 & 7 & 10 \\
\hline $5.5 * 6.5$ & 142 & 64 & 71 & 2591 & 33 & 33 & 133 & 0 & 0 \\
\hline $6.5-7.5$ & 101 & 45 & 60 & 2326 & 28 & 35 & 155 & 1 & 1 \\
\hline $7.5-8.5$ & 118 & 53 & 56 & 1947 & 26 & 33 & 199 & 6 & 10 \\
\hline $8.5-9.5$ & 185 & 83 & 90 & 3218 & 42 & 58 & 323 & 5 & 7 \\
\hline $9.5-10.5$ & 226 & 102 & 120 & 4302 & 56 & 53 & 229 & 4 & 11 \\
\hline $10.5-11.5$ & 212 & 95 & 110 & 3741 & 52 & 41 & 136 & 2 & 5 \\
\hline $11.5-12.5$ & 228 & 102 & 121 & 4453 & 57 & 55 & 219 & 3 & 5 \\
\hline $12.5-13.5$ & 178 & 80 & 81 & 2653 & 38 & 30 & 128 & 2 & 9 \\
\hline $13.5-14.5$ & 137 & 62 & 75 & 2860 & 35 & 28 & 199 & 4 & 9 \\
\hline $14.5-15.5$ & 82 & 37 & 34 & 1283 & 16 & 9 & 39 & 0 & 0 \\
\hline $15.5-16.5$ & 63 & 28 & 23 & 815 & 11 & 9 & 24 & 1 & 1 \\
\hline $16.5-17.5$ & 71 & 32 & 24 & 803 & 11 & 9 & 22 & 0 & 0 \\
\hline $17.5-18.5$ & 28 & 13 & 16 & 637 & 8 & 6 & 44 & 1 & 1 \\
\hline $18.5=$ & 8 & 4 & 2 & 8 & 1 & 1 & 1 & 0 & 0 \\
\hline Total & 4710 & 2116 & 2116 & 65463 & 992 & 992 & 4474 & 61 & 108 \\
\hline
\end{tabular}

Expected on the basis of distributing the number of film proportionally to the Years of Employment distribution.

s. Expected on the basis of distributing the No. of Employees with Measurable Readings proportionally to the distribution of No. of Employees Assigned Films.

Figure 5

CALENDAR YEAR 1960

\section{YEARS OF EMPLOYMENT AT TIME OF LATEST FILM READING WITHIN THE YEAR - BODY FILM DATA}

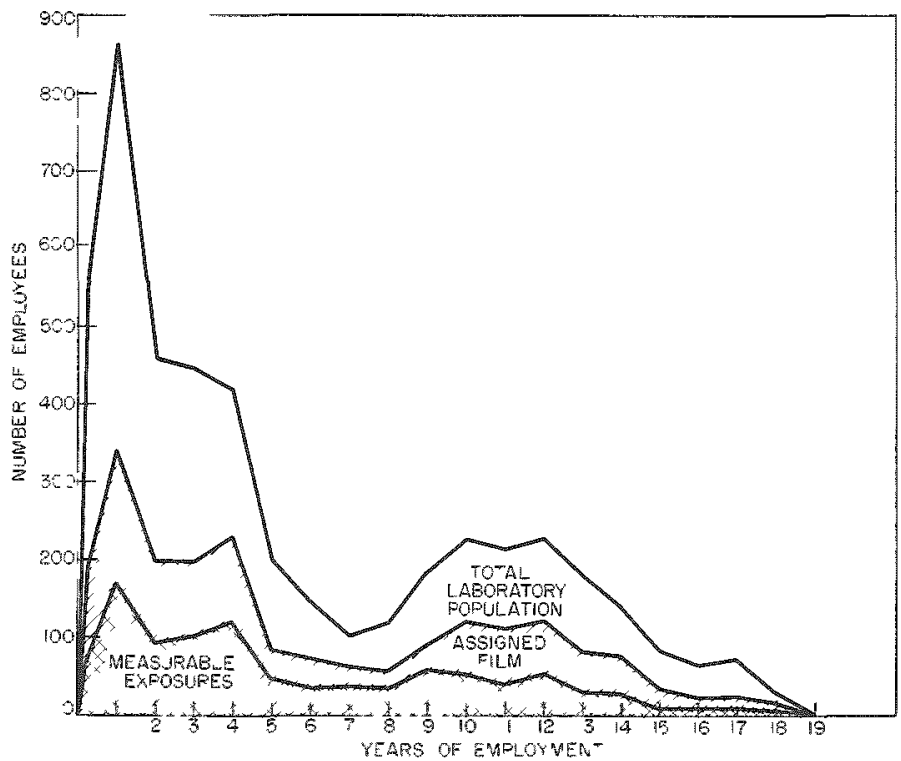


Table II

CALENDAR YEAR 1961

YEARS OF EMPLOYMENT AT TIME OF LATEST FILM READING WITHIN THE YEAR - BODY FILM DATA

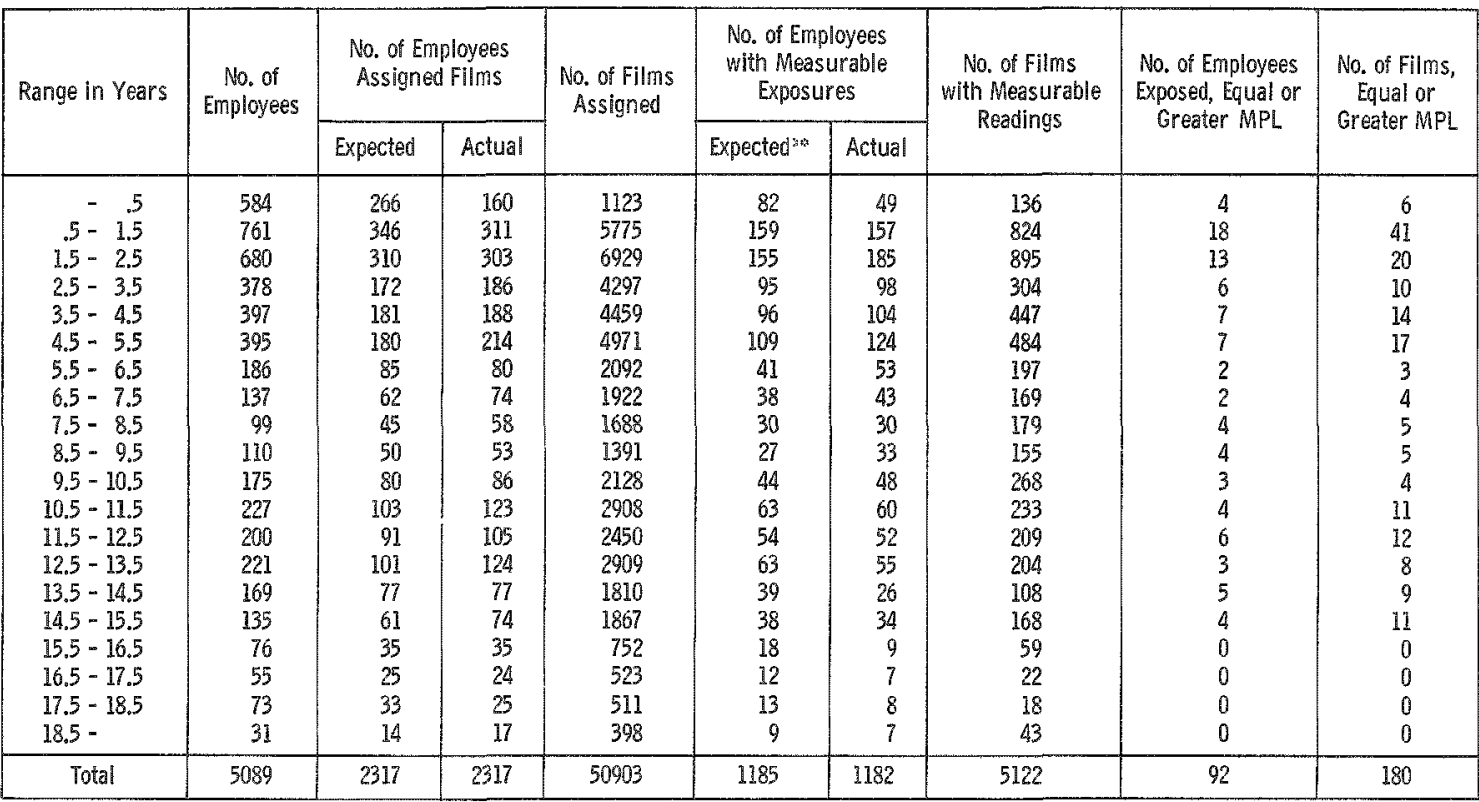

'Expected on the basis of distributing the number of film proportionally to the Years of Employment distribution.

$\cdots$ Expected on the basis of distributing the No. of Employees with Measurable Readings proportionally to the distribution of No. of Employees Assigned Films.

Figure 6

CALENDAR YEAR 1961
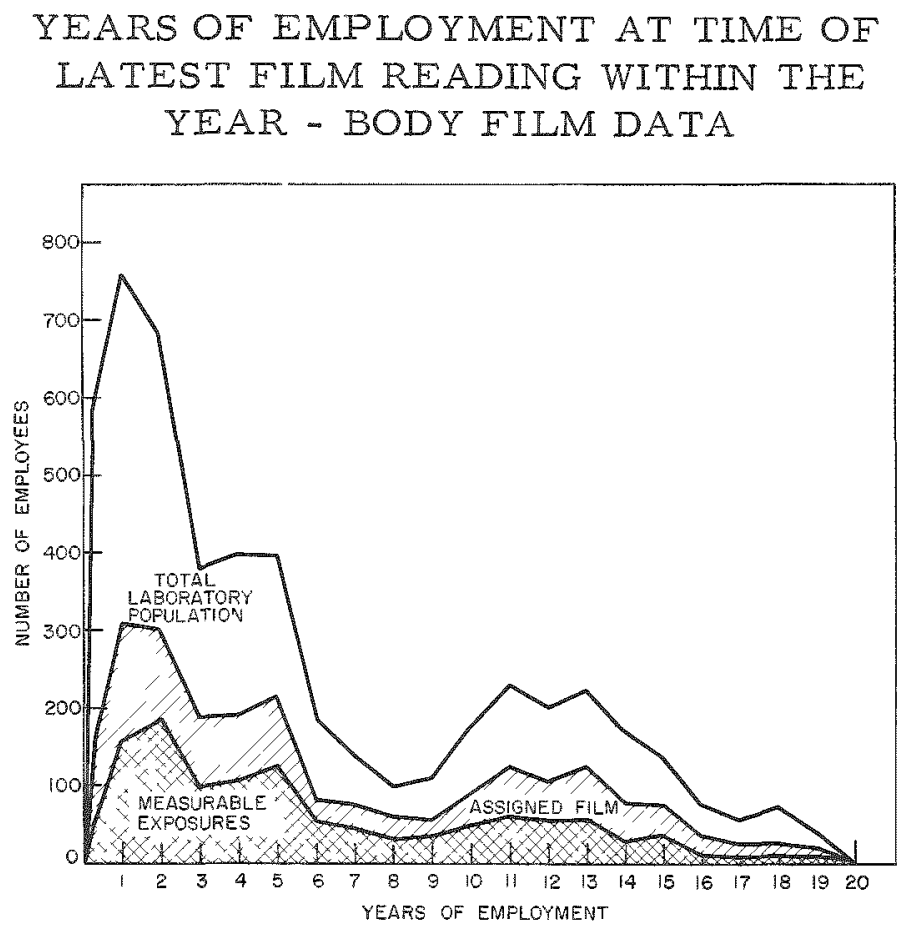
4. Laboratory Division at Time of Exposure to External Radiation, Tables VII-X

Table X shows the order of the Laboratory Divisions with respect to number of employees who receive measurable exposures. By pairing the rank order for any two of the three years and applying the data to the formula

$$
\rho=1-\frac{6 \sum D^{2}}{N\left(N^{2}-1\right)}
$$

where $\rho$ is the rank order correlation, $D$ is the difference between the paired items, and $N$ is the number of items, one gets the following correlations:

$\begin{array}{cc}\text { Paired Years } & \begin{array}{c}\text { Rank Order } \\ \text { Correlation }(\rho)\end{array} \\ 1959 \& 1960 & 0.77 \\ 1959 \& 1961 & 0.86 \\ 1960 \& 1961 & 0.93\end{array}$

It can be seen that the rank order has remained fairly constant. However, Table X reveals that a further study should be made of the combined divisions "Other Scientific" (Appendix A). The combined scientific divisions were not expected to rank so high on number of measurable exposures.

The Plant Services Division is the Division that has the largest number of employees who receive measurable exposures. This division includes reclamation and plant maintenance personnel. The exposures are received mostly by reclamation personnel who perform almost all of the significant decontamination work for the Laboratory.

The number of employees who receive measurable exposures in the combined divisions "Other Scientific" increased by 99 employees from 1959 to 1961. This increase in number of films with measurable exposure is attributed to the increase of low amount of exposure detected by extending the monitoring period and by using a more sensitive film. It should be noted in Tables VII-IX that the large increase occurred in 1960 when the Laboratory changed to the two-week monitoring period and a more sensitive film. The number of employees with measurable exposures increased considerably for nearly all divisions at that time. Employees receiving measurable exposures increased $73.7 \%$ from 1959-1960 while the increase in number monitored was $12.9 \%$. The changes in numbers of employees assigned film were not so significant. 
Tables VII-IX show that the Chemistry and Reactor Operations Divisions have the largest number of employees who exceeded the weekly MPL. The relative comparison of these two divisions to the total Laboratory population is as follows:

\begin{tabular}{|c|c|c|c|c|}
\hline \multirow{3}{*}{ Year } & \multicolumn{4}{|c|}{$\begin{array}{c}\text { PERCENTAGE CONTRIBUTED TO TOTAL EXPERIENCE } \\
\text { BY COMBINED CHEMISTRY AND REACTOR OPERATIONS }\end{array}$} \\
\cline { 2 - 5 } & $\begin{array}{c}\text { Total } \\
\text { Population }\end{array}$ & $\begin{array}{c}\text { Employees } \\
\text { Assigned Film }\end{array}$ & $\begin{array}{c}\text { Employees } \\
\text { with Measurable } \\
\text { Exposure }\end{array}$ & $\begin{array}{c}\text { Employees } \\
\text { Exposed } \\
\geq \text { MPL }\end{array}$ \\
\hline 1959 & 6.5 & 8.9 & 16.1 & 52.6 \\
1960 & 6.0 & 8.1 & 11.3 & 62.2 \\
1961 & 7.6 & 9.6 & 13.3 & 60.8 \\
\hline
\end{tabular}

The exposures in the Chemistry Division were incurred on the most part by personnel working in cyclotron-connected operations. The exposures received by the Reactor Operations Division were incurred by reactor operators involved in fuel changes, removing of samples from the reactor, and work involving reactor modification. Most of these exposures are connected with carefully controlled work. 
Table TIII

CALENDAR YEAR 1959

LABORATORY DIVISION AT TIME OF EXPOSURE TO EXTERNAL RADIATION - FILM DATA

\begin{tabular}{|c|c|c|c|c|c|c|c|c|c|}
\hline \multirow[t]{2}{*}{ Division Name } & \multirow{2}{*}{$\begin{array}{c}\text { No. of } \\
\text { Enployees }\end{array}$} & \multicolumn{2}{|c|}{$\begin{array}{l}\text { No. of Employees } \\
\text { Assigned films }\end{array}$} & \multirow{2}{*}{$\begin{array}{l}\text { No. of Films } \\
\text { Assigned }\end{array}$} & \multicolumn{2}{|c|}{$\begin{array}{c}\text { No. of Employees } \\
\text { with Measurable } \\
\text { Exposures }\end{array}$} & \multirow{2}{*}{$\begin{array}{l}\text { No. of Films } \\
\text { with Measurable } \\
\text { Readings }\end{array}$} & \multirow{2}{*}{$\begin{array}{l}\text { No. of Employees } \\
\text { Exposed, Equal or } \\
\text { Greater MPL }\end{array}$} & \multirow{2}{*}{$\begin{array}{l}\text { No. of films, } \\
\text { Equal or } \\
\text { Greater MPL }\end{array}$} \\
\hline & & Expected & Actual & & Expected*: & Actual & & & \\
\hline $\begin{array}{l}\text { 1. Plant Protection } \\
\text { 2. Plant Services } \\
\text { 3. Other Adm. and Gen. Services } \\
\text { 4. Idaho Division } \\
\text { 5. Metallurgy Division } \\
\text { 6. Chemical Engineering Division } \\
\text { 7. Reactor Engineering Research } \\
\text { 8. Chemistry Division } \\
\text { 9. Remote Control Engineering Division } \\
\text { 10. Other Scientific } \\
\text { 11. Reactor Operations } \\
\text { 12. Central Shops } \\
\text { 13. Industrial Hygiene and Safoty } \\
\text { 14. Fire Protection } \\
\text { 15. Other Technical Services }\end{array}$ & $\begin{array}{r}134 \\
421 \\
852 \\
83 \\
203 \\
212 \\
324 \\
216 \\
70 \\
937 \\
63 \\
440 \\
126 \\
44 \\
154 \\
\end{array}$ & $\begin{array}{r}59 \\
184 \\
373 \\
36 \\
89 \\
93 \\
142 \\
95 \\
31 \\
410 \\
28 \\
193 \\
55 \\
19 \\
67\end{array}$ & $\begin{array}{r}131 \\
215 \\
112 \\
79 \\
163 \\
208 \\
148 \\
109 \\
16 \\
327 \\
58 \\
137 \\
73 \\
42 \\
56 \\
\end{array}$ & $\begin{array}{r}6686 \\
8254 \\
3074 \\
2606 \\
7885 \\
9912 \\
6145 \\
4788 \\
668 \\
12667 \\
2859 \\
4829 \\
3658 \\
2039 \\
2528 \\
\end{array}$ & $\begin{array}{r}40 \\
66 \\
34 \\
24 \\
50 \\
63 \\
45 \\
33 \\
5 \\
100 \\
18 \\
42 \\
22 \\
13 \\
17\end{array}$ & $\begin{array}{r}1 \\
72 \\
35 \\
62 \\
32 \\
29 \\
64 \\
38 \\
7 \\
75 \\
54 \\
56 \\
36 \\
0 \\
10\end{array}$ & $\begin{array}{r}1 \\
659 \\
70 \\
401 \\
182 \\
107 \\
202 \\
297 \\
89 \\
168 \\
686 \\
173 \\
283 \\
0 \\
40 \\
\end{array}$ & $\begin{array}{r}0 \\
7 \\
1 \\
1 \\
4 \\
0 \\
6 \\
15 \\
2 \\
2 \\
25 \\
9 \\
3 \\
0 \\
1 \\
\end{array}$ & $\begin{array}{r}0 \\
11 \\
2 \\
2 \\
4 \\
0 \\
7 \\
30 \\
4 \\
3 \\
47 \\
13 \\
3 \\
0 \\
1 \\
\end{array}$ \\
\hline Total & 4279 & 1874 & 1874 & 78598 & 572 & 571 & 3357 & 76 & 127 \\
\hline
\end{tabular}

"Expected on the basis of distributing the number of film proportionally to the Division distribution.

waspected on the basis of distributing the No. of Employees with Measurable Readings proportionally io the distribution of No. of Employees Assigned Films.

Figure 7

CALENDAR YEAR 1959

\section{LABORATORY DIVISION AT TIME OF EXPOSURE TO EXTERNAL RADIATION - FILM DATA}

\begin{tabular}{|c|c|c|c|c|c|c|c|}
\hline \multirow{2}{*}{ Division } & \multicolumn{7}{|c|}{ Number of Employees } \\
\hline & 100 & 300 & 500 & 700 & 900 & 1100 & 1300 \\
\hline Plant Protection & $\Longrightarrow$ & 1 & & & & & \\
\hline Plant Services & & & & & 1 & & \\
\hline Other Adm. and Gen. Services & & & & & - Not & f Film & \\
\hline Idaho Division & ] & & & & & & \\
\hline Metallurgy Division & & & & & 1 & i & \\
\hline Chemical Engineering Division & & Assig & $-N_{0}$ & le Exp & & & \\
\hline Reactor Engineering Division & & & & & 1 & 1 & 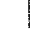 \\
\hline Chemistry Division & & & & & : & 1 & \\
\hline Remote Control Engineering Di & & 1 & & & 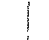 & & \\
\hline Other Scientific & & 言 & & & & & \\
\hline Reactor Operations & & & & & 1 & 1 & \\
\hline Central Shops & & & & $i$ & & 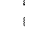 & \\
\hline Industrial Hygiene and Safety & $\equiv$ & 1 & & & & & \\
\hline Fire Protection & 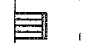 & t & ? & 1 & 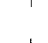 & I & \\
\hline Other Technical Services & 0 & & & 1 & & & \\
\hline
\end{tabular}


Table VIII

CALENDAR YEAR 1960

LABORATORY DIVISION AT TIME OF EXPOSURE TO EXTERNAL RADIATION - FILM DATA

\begin{tabular}{|c|c|c|c|c|c|c|c|c|c|}
\hline \multirow[t]{2}{*}{ Division Name } & \multirow[t]{2}{*}{$\begin{array}{c}\text { No. of } \\
\text { Employees }\end{array}$} & \multicolumn{2}{|c|}{$\begin{array}{l}\text { No. of Employees } \\
\text { Assigned Films }\end{array}$} & \multirow[t]{2}{*}{$\begin{array}{l}\text { No. of Films } \\
\text { Assigned }\end{array}$} & \multicolumn{2}{|c|}{$\begin{array}{c}\text { No. of Employees } \\
\text { with Measurable } \\
\text { Exposures }\end{array}$} & \multirow{2}{*}{$\begin{array}{c}\text { No of Films } \\
\text { with Measurable } \\
\text { Readings }\end{array}$} & \multirow{2}{*}{$\begin{array}{l}\text { No. of Employees } \\
\text { Exposed, Equal or } \\
\text { Greater MPL }\end{array}$} & \multirow{2}{*}{$\begin{array}{l}\text { No, of Films, } \\
\text { Equal or } \\
\text { Greater MPL }\end{array}$} \\
\hline & & Expected & Actual & & Expected: & Actual & & & \\
\hline 1. Plant Protection & 129 & 58 & 126 & 5186 & 59 & 11 & 12 & 0 & 0 \\
\hline 2. Plant Services & 458 & 206 & 233 & 6450 & 109 & 125 & 596 & 7 & 9 \\
\hline 3. Other Adm. and Gen. Services & 950 & 427 & 157 & 2495 & 74 & 51 & 75 & 0 & 0 \\
\hline 4. Idaho Division & 155 & 70 & 150 & 3572 & 70 & 98 & 751 & 0 & 0 \\
\hline 5. Metallurgy Division & 224 & 101 & 192 & 7573 & 90 & 88 & 350 & 6 & 7 \\
\hline 6. Chemical Engineering Division & 223 & 100 & 222 & 7934 & 104 & 99 & 229 & 0 & 0 \\
\hline 7. Reactor Engineering Research & 310 & 139 & 152 & 4814 & 71 & 73 & 237 & 0 & 0 \\
\hline 8. Chemistry Division & 215 & 97 & 107 & 4087 & 50 & 50 & 410 & 14 & 24 \\
\hline 9. Remote Control Engineering Division & 76 & 34 & 28 & 936 & 13 & 13 & 126 & 1 & 2 \\
\hline 10. Other Scientific & 1114 & 500 & 375 & 9885 & 176 & 150 & 349 & 3 & 3 \\
\hline 11. Reactor operations & 70 & 31 & 65 & 2472 & 30 & 62 & 749 & 24 & 57 \\
\hline 12. Central Shops & 464 & 208 & 137 & 3616 & 64 & 71 & 154 & 1 & 1 \\
\hline 13. Industrial Hygiene and Safety & 123 & 55 & 76 & 2821 & 36 & 49 & 336 & 5 & 5 \\
\hline 14. Fire Protection & 43 & 19 & 41 & 1620 & 19 & 23 & 32 & 0 & 0 \\
\hline 15. Other Technical Services & 156 & 70 & 55 & 2002 & 26 & 29 & 68 & 0 & 0 \\
\hline Total & 4710 & 2115 & 2116 & 65463 & 991 & 992 & 4474 & 61 & 108 \\
\hline
\end{tabular}

"Expected on the basis of distributing the number of film propertionally to the Division distribution.

* Expected on the basis of distributing the No. of Employees with Measurable Readings proportionally to the distribution of No. of Employees Assigned Films.

Figure 8

CALENDAR YEAR 1960

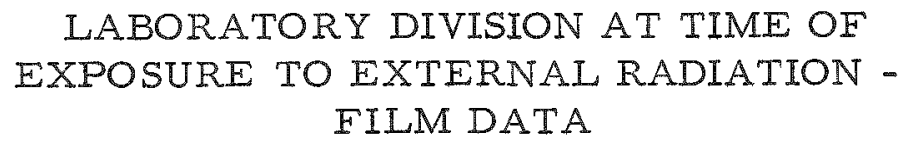

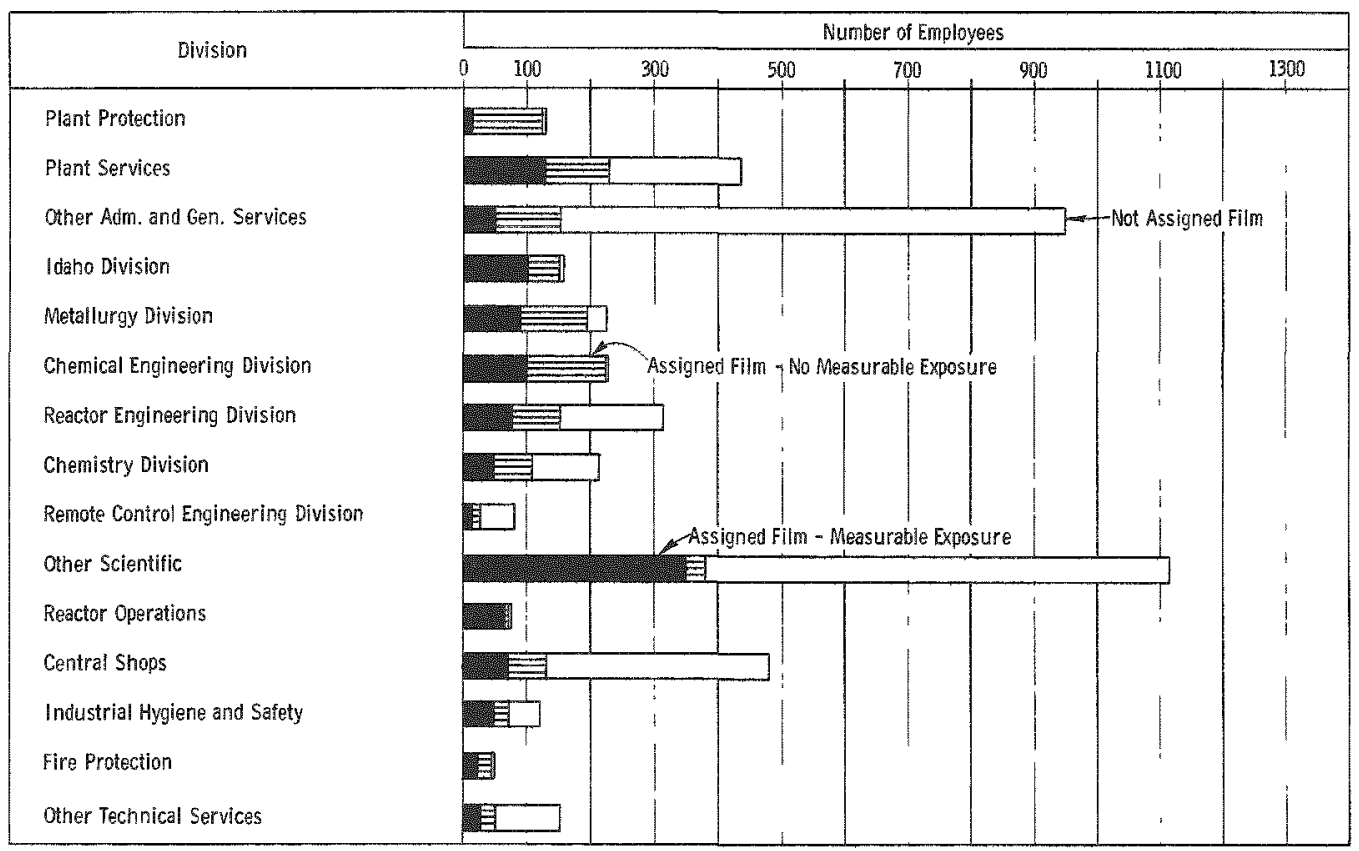


Table IX

CALENDAR YEAR 1961

LABORATORY DIVISION AT TIME OF EXPOSURE TO EXTERNAL RADIATION - FILM DATA

\begin{tabular}{|c|c|c|c|c|c|c|c|c|c|}
\hline \multirow[t]{2}{*}{ Division Name } & \multirow{2}{*}{$\begin{array}{c}\text { No. of } \\
\text { Employees }\end{array}$} & \multicolumn{2}{|c|}{$\begin{array}{l}\text { No. of Employees } \\
\text { Assigned Films }\end{array}$} & \multirow{2}{*}{$\begin{array}{c}\text { No. of Films } \\
\text { Assigned }\end{array}$} & \multicolumn{2}{|c|}{$\begin{array}{c}\text { No. of Employees } \\
\text { with Measurable } \\
\text { Exposures }\end{array}$} & \multirow{2}{*}{$\begin{array}{l}\text { No. of Films } \\
\text { with Measurabie } \\
\text { Reatings }\end{array}$} & \multirow{2}{*}{$\begin{array}{l}\text { No. of Employees } \\
\text { Exposed, Equal or } \\
\text { Greater MPL }\end{array}$} & \multirow{2}{*}{$\begin{array}{l}\text { No. of Films, } \\
\text { Equal or } \\
\text { Greater MPL }\end{array}$} \\
\hline & & Expected" & Actual & & Expected ${ }^{* * 3}$ & Actual & & & \\
\hline 1. Plant Protection & 123 & 56 & 120 & 3107 & 61 & 39 & 53 & 0 & 0 \\
\hline 2. Plant Services & 481 & 219 & 238 & 4463 & 121 & 124 & 542 & 10 & 11 \\
\hline 3. Other Adm, and Gen. Services & 1002 & 456 & 208 & 3524 & 106 & 72 & 156 & 4 & 5 \\
\hline 4. Idaho Division & 217 & 99 & 212 & 5430 & 108 & 117 & 689 & 4 & 4 \\
\hline 5. Metallurgy Division & 230 & 105 & 184 & 4576 & 94 & 90 & 359 & 2 & 4 \\
\hline 6. Chemical Engineering Division & 287 & 112 & 246 & 5660 & 125 & 86 & 228 & 1 & 1 \\
\hline 7. Reactor Engineering Research & 313 & 143 & 173 & 3869 & 88 & 103 & 310 & 3 & 4 \\
\hline 8. Chemistry Division & 294 & 134 & 134 & 3138 & 68 & 72 & 388 & 11 & 14 \\
\hline 9. Remote Control Engineering Division & 78 & 36 & $3 A$ & 645 & 17 & 19 & 137 & 1 & 2 \\
\hline 10. Other Scientitic & 1150 & 524 & 349 & 6990 & 178 & 174 & 454 & 3 & 3 \\
\hline 11. Reactor Operations & 93 & 42 & 89 & 2322 & 45 & 87 & 1036 & 45 & 121 \\
\hline 12. Central Shops & 496 & 226 & 140 & 2558 & 71 & 75 & 168 & 2 & 2 \\
\hline 13. Industrial Hygiene and Safety & 132 & 60 & 89 & 2121 & 45 & 68 & 434 & 6 & 9 \\
\hline 14. Fire Protection & 44 & 20 & 42 & 1126 & 21 & 27 & 58 & 0 & 0 \\
\hline 15. Other Technical Services & 189 & 86 & 59 & 1374 & 30 & 29 & 110 & 0 & 0 \\
\hline Total & 5089 & 2318 & 2317 & 50903 & 1178 & 1182 & 5122 & 92 & 180 \\
\hline
\end{tabular}

"Expected on the basis of distributing the number of fllm proportionally to the Division distribution.

waxpected on the basis of distributing the No. of Employees with Measurable Readings proportionally to the distribution of No. of Employees Assigned Films.

Figure 9

CALENDAR YEAR 1961

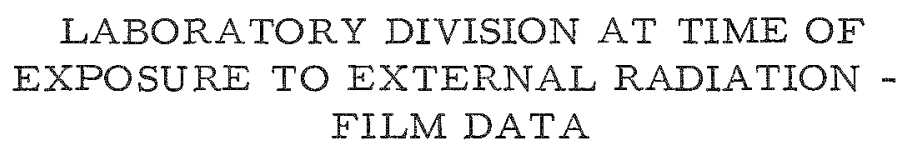

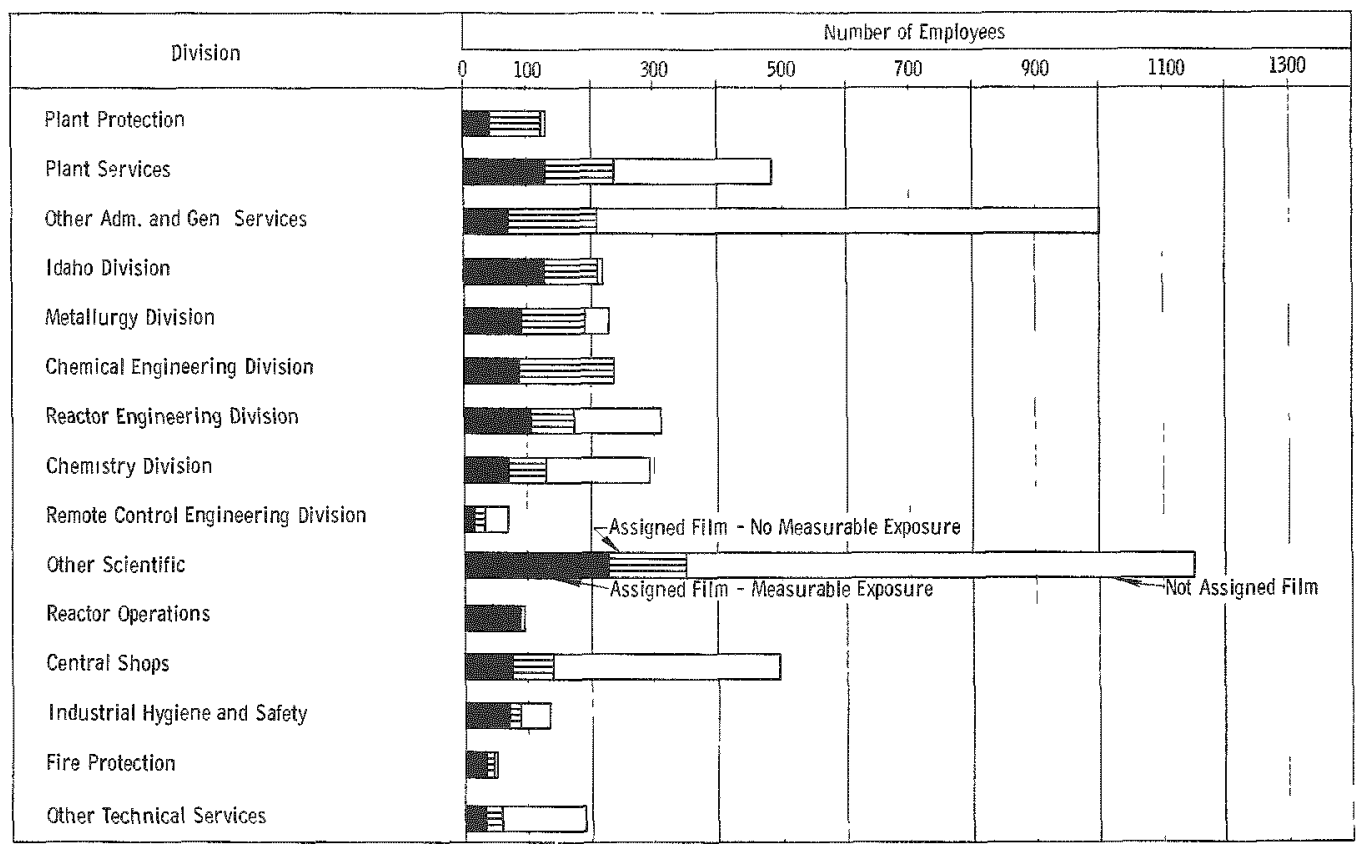


Table X

RANK ORDER OF LABORATORY DIVISION AT TIME OF EXPOSURE TO EXTERNAL RADTATION BY NO. OF EMPLOYEES WITH MEASURABLE EXPOSURES

\begin{tabular}{|c|c|c|c|c|c|c|c|}
\hline \multirow[t]{2}{*}{ Dirision } & \multicolumn{3}{|c|}{$\begin{array}{c}\text { Rank Order from } \\
\text { Highest to } \\
\text { Lowest No. }\end{array}$} & \multirow[t]{2}{*}{ Division } & \multicolumn{3}{|c|}{$\begin{array}{c}\text { Rank Order from } \\
\text { Highest to } \\
\text { Lowest No. }\end{array}$} \\
\hline & 1959 & 1960 & 1961 & & 1959 & 1960 & 1961 \\
\hline Other Scientific & 1 & $I$ & 1 & Other Adm. and General Serv. & 9 & 9 & 9.5 \\
\hline Plant Services & 2 & 2 & 2 & Metallurgy Division & 10 & 5 & 5 \\
\hline Reactor Engineering & 3 & 6 & \pm & Chemical Engineering Div. & 11 & 3 & 7 \\
\hline Idaho Division & 4 & 4 & 3 & Other Technical Services & 12 & 12 & 13 \\
\hline Central Shops & 5 & 7 & 8 & Remote Control Engineering & 13 & 14 & 15 \\
\hline Reactor Operations & 6 & 8 & 6 & Plant Protection & 14 & 15 & 12 \\
\hline Chemistry Division & 7 & 10 & 9.5 & Fire Protection & 15 & 13 & 14 \\
\hline Industrial Hygiene and Safety & 8 & 11 & 11 & & & & \\
\hline
\end{tabular}

5. Job Group at Time of Exposure to External Radiation, Tables XI-XIV

The Job Groups define to some extent the type of work being done by the employees in the distributions. For example, Administrative Staff personnel are primaxily engaged in the managerial aspect of the Laboratory, whereas Scientific Staff personnel are primarily engaged in research and development work. The Technician assists the Scientist in setting up projects for experiment and is responsible for securing data. The category of Maintenance includes all job groups whose responsibility it is to service the Laboratory's physical plant. These would include the Carpenters, Painters, Electricians, Pipefitters, etc. The category of Services includes job groups that provide a supporting service to the scientific and other Laboratory personnel. The two job groups included in this category that are most significant in view of receiving exposures to radioactivity are the Special Materials Representatives and Reclamation Men. Personnel in either job group frequently encounter radioactive materials. The Clerical category includes Secretaries, Stenographers, Clerks, Typists, etc., and the Central Shops category includes all job groups that are commonly as sociated with the shops, such as Machinists, Welders, Grinders, etc. The category of Reactor Operators includes those who operate and maintain the reactors of the Laboratory.

Tables XI-XIII and Figs. 10-12 show that the Technicians have the largest number of employees and films with measurable readings. Table XIV shows that, in relation to the number of employees assigned film, the Technicians have received more than their proportionate share of measurable exposures.

Table XIV also shows that the Reactor Operators receive more than their proportionate share of the measurable exposures. They represent a small percentage of the employees with measurable exposures, but a rather high percentage of the employees that exceed the weekly maximum permissible levels. Practically every Reactor Operator receives a measurable exposure, and nearly as many employees in this group exceed weekly MPLs as in the Technician group. 
Table XI

CALENOAR YEAR 1959

JOB GROUP AT TIME OF EXPOSURE TO EXTERNAL RADIATION - FILM DATA

\begin{tabular}{|c|c|c|c|c|c|c|c|c|c|c|}
\hline \multirow{2}{*}{\multicolumn{2}{|c|}{ Job Group }} & \multirow{2}{*}{$\begin{array}{c}\text { No, of } \\
\text { Employees }\end{array}$} & \multicolumn{2}{|c|}{$\begin{array}{l}\text { No. of Employees } \\
\text { Assigned Films }\end{array}$} & \multirow[t]{2}{*}{$\begin{array}{l}\text { No. of Films } \\
\text { Assigned }\end{array}$} & \multicolumn{2}{|c|}{$\begin{array}{c}\text { No. of Employees } \\
\text { with Measurable } \\
\text { Exposures }\end{array}$} & \multirow{2}{*}{$\begin{array}{l}\text { No. of Films } \\
\text { with Measurable } \\
\text { Readings }\end{array}$} & \multirow{2}{*}{$\begin{array}{l}\text { No. of Employees } \\
\text { Exposed, Equal or } \\
\text { Greater MPL }\end{array}$} & \multirow{2}{*}{$\begin{array}{l}\text { No. of Films, } \\
\text { Equal or } \\
\text { Greater MPL }\end{array}$} \\
\hline & & & Expected & Actual & & Expected & Actual & & & \\
\hline $\begin{array}{l}\text { A. } \\
\text { B. } \\
\text { C. } \\
\text { D. } \\
\text { E. } \\
\text { F. } \\
\text { G. } \\
\text { H. } \\
\text { I. }\end{array}$ & $\begin{array}{l}\text { Adninistrative Staff } \\
\text { Scientific Staff } \\
\text { Technicians } \\
\text { Maintenance } \\
\text { Services } \\
\text { Clerical } \\
\text { Shops } \\
\text { Reactor Operators } \\
\text { Miscellaneous }\end{array}$ & $\begin{array}{r}271 \\
1041 \\
733 \\
390 \\
333 \\
560 \\
329 \\
37 \\
585 \\
\end{array}$ & $\begin{array}{r}119 \\
456 \\
321 \\
171 \\
146 \\
245 \\
144 \\
16 \\
256 \\
\end{array}$ & $\begin{array}{r}108 \\
533 \\
459 \\
201 \\
218 \\
67 \\
113 \\
37 \\
138\end{array}$ & $\begin{array}{r}4116 \\
23488 \\
20967 \\
7437 \\
10781 \\
1717 \\
3726 \\
1996 \\
4370 \\
\end{array}$ & $\begin{array}{r}33 \\
162 \\
140 \\
61 \\
66 \\
20 \\
34 \\
11 \\
42\end{array}$ & $\begin{array}{r}22 \\
139 \\
175 \\
68 \\
28 \\
12 \\
52 \\
37 \\
38\end{array}$ & $\begin{array}{r}94 \\
591 \\
1128 \\
193 \\
525 \\
14 \\
168 \\
569 \\
75\end{array}$ & $\begin{array}{r}2 \\
11 \\
23 \\
2 \\
7 \\
0 \\
9 \\
21 \\
1\end{array}$ & $\begin{array}{r}3 \\
20 \\
33 \\
3 \\
11 \\
0 \\
13 \\
42 \\
2\end{array}$ \\
\hline & Total & 4279 & 1874 & 1874 & 78598 & 569 & 571 & 3357 & 76 & 127 \\
\hline
\end{tabular}

Expected on the basis of distributing the number of film proportionally to the Job Group distribution.

"Expected on the basis of distributing the No. of Employees with Measurahle Readings proportionally to the distribution of No. of Employees Assigned Films.

Figure 10

CALENDAR YEAR 1959

\section{JOB GROUP AT TIME OF EXPOSURE TO EXTERNAL RADIATION - FILM DATA}

\begin{tabular}{|l|l|l|l|}
\hline Job Group & Number of Employees \\
Scientific Staff & Technicians \\
Services \\
Clerical \\
Shops \\
Reactor Operators \\
Miscellaneous
\end{tabular}


Table XII

CALENDAR YEAR 1960

JOB GROUP AT TIME OF EXPOSURE TO EXTERNAL RADIATION - FILM DATA

\begin{tabular}{|c|c|c|c|c|c|c|c|c|c|}
\hline \multirow[t]{2}{*}{ Job Group } & \multirow{2}{*}{$\begin{array}{c}\mathrm{No} \text {. of } \\
\text { Employees }\end{array}$} & \multicolumn{2}{|c|}{$\begin{array}{l}\text { No. of Employees } \\
\text { Assigned Films }\end{array}$} & \multirow{2}{*}{$\begin{array}{l}\text { No. of films } \\
\text { Asstgned }\end{array}$} & \multicolumn{2}{|c|}{$\begin{array}{c}\text { No. of Employees } \\
\text { with Measurable } \\
\text { Exposures }\end{array}$} & \multirow{2}{*}{$\begin{array}{c}\text { No. of Filns } \\
\text { with Measurable } \\
\text { Readings }\end{array}$} & \multirow{2}{*}{$\begin{array}{l}\text { No. of Employees } \\
\text { Exposed, Equal or } \\
\text { Greater MPL }\end{array}$} & \multirow{2}{*}{$\begin{array}{l}\text { No. of Films, } \\
\text { Equal or } \\
\text { Greater MPL }\end{array}$} \\
\hline & & Expected" & Actual & & Expected;:* & Actual & & & \\
\hline $\begin{array}{l}\text { A. Administrative Staff } \\
\text { B. Scientific Staff } \\
\text { C. Technicians } \\
\text { D. Maintenance } \\
\text { E. Services } \\
\text { F. Clerical } \\
\text { G. Shops } \\
\text { H. Reactor Operators } \\
\text { 1. Miscellaneous }\end{array}$ & $\begin{array}{r}325 \\
1093 \\
865 \\
440 \\
344 \\
619 \\
341 \\
44 \\
639\end{array}$ & $\begin{array}{r}146 \\
491 \\
389 \\
198 \\
155 \\
278 \\
153 \\
20 \\
287\end{array}$ & $\begin{array}{r}121 \\
567 \\
571 \\
232 \\
221 \\
83 \\
111 \\
44 \\
166\end{array}$ & $\begin{array}{r}3205 \\
18476 \\
19927 \\
5801 \\
8500 \\
1613 \\
2856 \\
1731 \\
3354\end{array}$ & $\begin{array}{r}57 \\
266 \\
268 \\
109 \\
104 \\
39 \\
52 \\
21 \\
78\end{array}$ & $\begin{array}{r}39 \\
267 \\
330 \\
115 \\
72 \\
17 \\
61 \\
43 \\
48\end{array}$ & $\begin{array}{r}105 \\
883 \\
1939 \\
232 \\
484 \\
30 \\
139 \\
577 \\
85\end{array}$ & $\begin{array}{r}0 \\
12 \\
21 \\
0 \\
7 \\
0 \\
1 \\
18 \\
2\end{array}$ & $\begin{array}{r}0 \\
20 \\
32 \\
0 \\
9 \\
0 \\
1 \\
44 \\
2 \\
\end{array}$ \\
\hline Total & 4710 & 2117 & 2116 & 65463 & 994 & 992 & 4474 & 61 & 108 \\
\hline
\end{tabular}

"Expected on the basis of distributing the number of film proportionally to the Job Group distribution.

$\Rightarrow$ Expected on the basis of distributing the No, of Employees with Measurable Readings proportionally to the distribution

of No. of Employees Assigned Films.

Figure 11

CALENDAR YEAR 1960

\section{JOB GROUP AT TIME OF EXPOSURE TO \\ EXTERNAL RADIATION - FILM DATA}

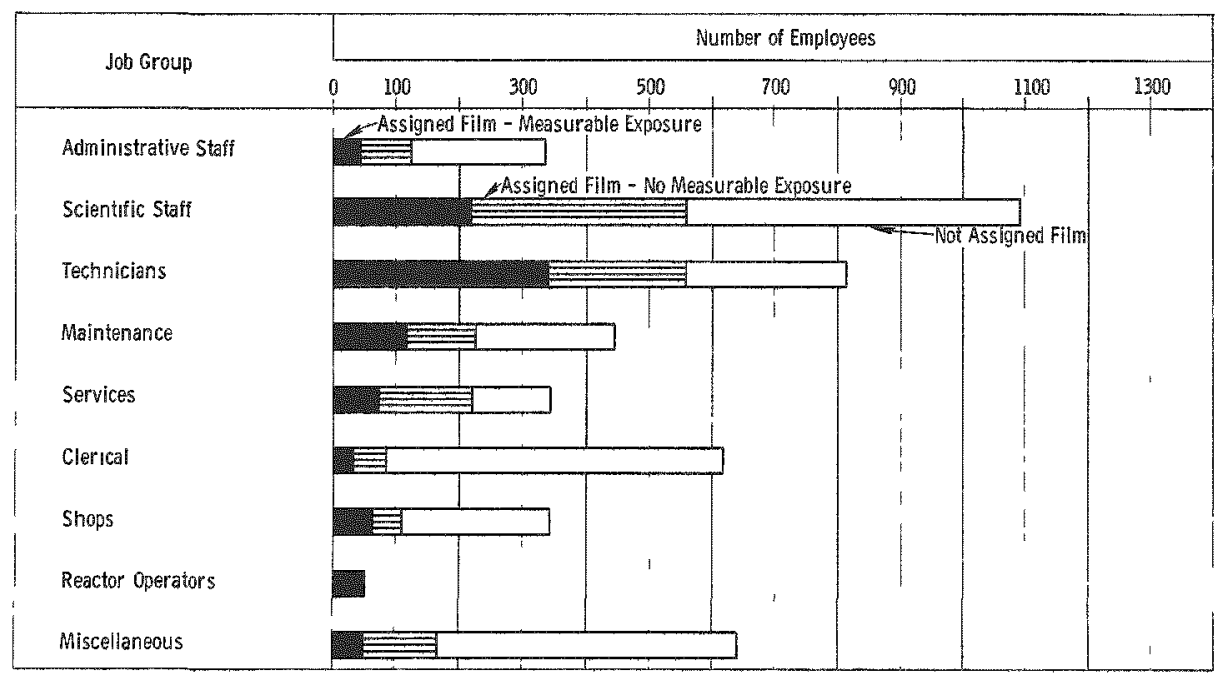


Table XII

CALENDAR YEAR 1961

JOB GROUP AT TIME OF EXPOSURE TO EXTERNAL RADIATION - FIUM DATA

\begin{tabular}{|c|c|c|c|c|c|c|c|c|c|}
\hline \multirow[t]{2}{*}{ Job Group } & \multirow{2}{*}{$\begin{array}{c}\text { No. of } \\
\text { Employees }\end{array}$} & \multicolumn{2}{|c|}{$\begin{array}{l}\text { No. of Employees } \\
\text { Assigned Films }\end{array}$} & \multirow{2}{*}{$\begin{array}{l}\text { No. of Films } \\
\text { Assigned }\end{array}$} & \multicolumn{2}{|c|}{$\begin{array}{l}\text { No. of Employees } \\
\text { with Measurable } \\
\text { Exposures }\end{array}$} & \multirow{2}{*}{$\begin{array}{l}\text { No. of Films } \\
\text { with Measurable } \\
\text { Readings }\end{array}$} & \multirow{2}{*}{$\begin{array}{c}\text { No. of Employees } \\
\text { Exposed, Equal or } \\
\text { Greater MPL }\end{array}$} & \multirow{2}{*}{$\begin{array}{l}\text { No. of Films, } \\
\text { Equal or } \\
\text { Greater MPL }\end{array}$} \\
\hline & & Expected: & Actual & & Expectedto & Actual & & & \\
\hline $\begin{array}{l}\text { A. Admınistrative Staff } \\
\text { B. Scientific Staff } \\
\text { C. Technicians } \\
\text { D. Maintenance } \\
\text { E. Services } \\
\text { F. Clerical } \\
\text { G. Shops } \\
\text { H. Reactor operators } \\
\text { 1. Miscellaneous }\end{array}$ & $\begin{array}{r}336 \\
1153 \\
1020 \\
471 \\
358 \\
652 \\
347 \\
58 \\
694\end{array}$ & $\begin{array}{r}153 \\
525 \\
464 \\
214 \\
163 \\
297 \\
158 \\
26 \\
316 \\
\end{array}$ & $\begin{array}{r}131 \\
605 \\
665 \\
248 \\
233 \\
90 \\
114 \\
58 \\
173 \\
\end{array}$ & $\begin{array}{r}2420 \\
14004 \\
16121 \\
4763 \\
6026 \\
1292 \\
2084 \\
1559 \\
2634 \\
\end{array}$ & $\begin{array}{r}67 \\
309 \\
339 \\
126 \\
119 \\
46 \\
58 \\
30 \\
88 \\
\end{array}$ & $\begin{array}{r}51 \\
288 \\
399 \\
116 \\
116 \\
28 \\
71 \\
57 \\
56 \\
\end{array}$ & $\begin{array}{r}132 \\
957 \\
2137 \\
265 \\
548 \\
42 \\
159 \\
756 \\
126 \\
\end{array}$ & $\begin{array}{r}2 \\
15 \\
25 \\
5 \\
7 \\
0 \\
2 \\
33 \\
3 \\
\end{array}$ & $\begin{array}{r}2 \\
20 \\
40 \\
6 \\
8 \\
0 \\
2 \\
97 \\
5\end{array}$ \\
\hline Total & 5089 & 2316 & 2317 & 50903 & 1182 & 1182 & 5122 & 92 & 180 \\
\hline
\end{tabular}

"Expected on the basis of distributing the number of fim proportionally to the Job Group distribution.

$\Rightarrow$ Expected on the basis of distributing the No. of Employees with Measurable Readings proportionally to the distribution of No. of Employees Assigned Films.

Figure 12

CALENDAR YEAR 1961

JOB GROUP AT TIME OF EXPOSURE TO
EXTERNAL RADIATION - FILM DATA

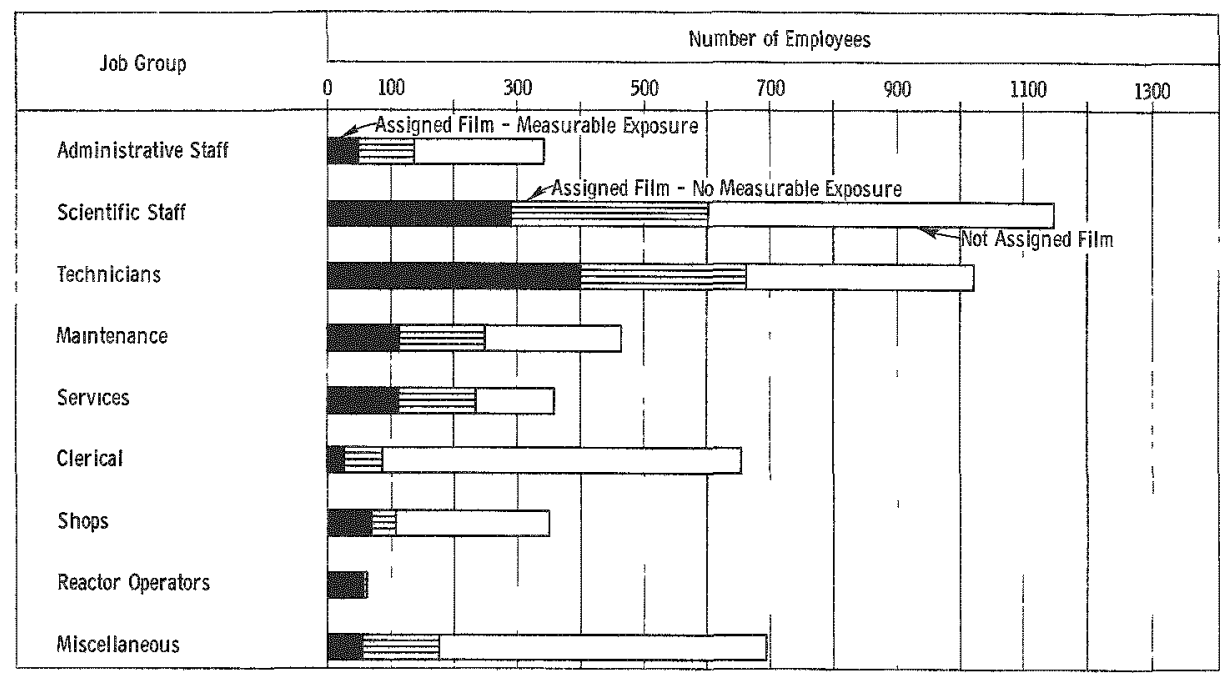


Table XIV

PERCENT OF EXPOSURE EXPERIENCE REPRESENTED BY EACH JOB GROUP

\begin{tabular}{|l|r|r|r|r|r|r|r|r|r|r|r|r|r|}
\hline \multirow{2}{*}{ Job Group } & \multicolumn{3}{|c|}{$\begin{array}{c}\text { Employees with } \\
\text { Assigned Film }\end{array}$} & \multicolumn{3}{c|}{$\begin{array}{c}\text { Employes with } \\
\text { Measurable } \\
\text { Exposure }\end{array}$} & \multicolumn{3}{c|}{$\begin{array}{c}\text { Film with } \\
\text { Measurable } \\
\text { Exposure }\end{array}$} & \multicolumn{3}{c|}{$\begin{array}{c}\text { Employees } \geq \\
\text { Weeklv MPI }\end{array}$} \\
\cline { 2 - 13 } & 1959 & 1960 & 1961 & 1959 & 1960 & 1961 & 1959 & 1960 & 1961 & 1959 & 1960 & 1961 \\
\hline Administrative Staff & 5.8 & 5.7 & 5.7 & 3.9 & 3.9 & 4.3 & 2.8 & 2.3 & 2.6 & 2.3 & 0 & 1.1 \\
Scientific Staff & 28.4 & 26.8 & 26.1 & 24.3 & 26.9 & 24.4 & 17.6 & 19.7 & 18.7 & 15.7 & 18.5 & 11.1 \\
Technicians & 24.5 & 27.0 & 28.7 & 30.6 & 33.3 & 33.8 & 33.6 & 43.4 & 41.7 & 26.0 & 29.6 & 22.2 \\
Maintenance & 10.7 & 11.0 & 10.7 & 11.9 & 11.6 & 9.8 & 5.8 & 5.2 & 5.2 & 2.4 & 0 & 3.3 \\
Services & 11.6 & 10.4 & 10.0 & 4.9 & 7.3 & 9.8 & 15.6 & 10.8 & 10.7 & 8.7 & 8.3 & 4.5 \\
Clexical & 3.6 & 3.9 & 3.9 & 2.1 & 1.7 & 2.4 & 0.4 & 0.7 & 0.8 & 0 & 0 & 0 \\
Shops & 6.0 & 5.3 & 4.9 & 9.1 & 6.2 & 6.0 & 5.0 & 3.1 & 3.1 & 10.2 & 0.9 & 1.1 \\
Reactor Operators & 2.0 & 2.1 & 2.5 & 6.5 & 4.3 & 4.8 & 17.0 & 12.9 & 14.8 & 33.1 & 40.8 & 53.9 \\
Miscellaneous & 7.4 & 7.8 & 7.5 & 6.7 & 4.8 & 4.7 & 2.2 & 1.9 & 2.4 & 1.6 & 1.9 & 2.8 \\
\hline
\end{tabular}

6. Sex of ANL Employees Exposed to External Radiation, Tables XV-XVII

As a matter of interest, the distribution of male and female employees for each year was determined. It is of interest to note that over the three years the females have received their proportionate share of the measurable exposures. The ratio of females to males that are assigned film is 0.08 , and the ratio of females to males that receive measurable exposure is 0.08 . 
Table XV

CALENDAR YEAR 1959

SEX OF ANL EMPLOVESS EXPOSED TO EXTERNAL RADIATION - BODY FILM DATA

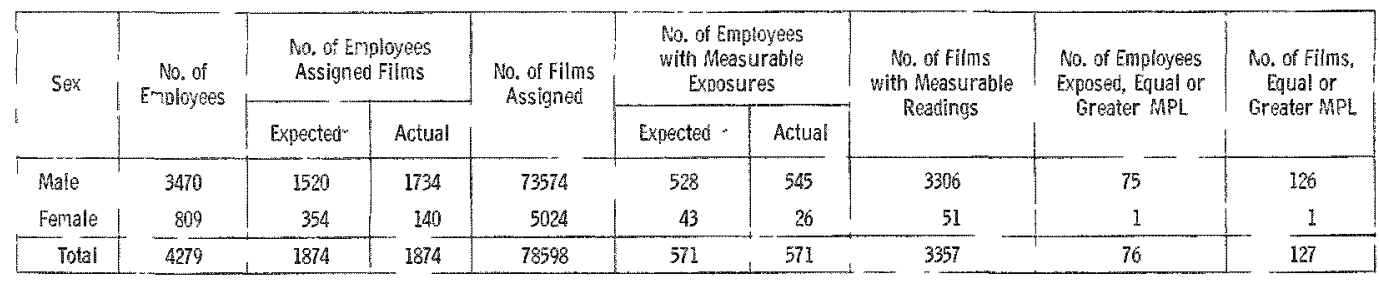

Expected on the basis of distributing the number ffilm proportionally to the Job Groun distribution.

"Expected on the basis of distributing the No. of Employees with Measurable Readings proportionally to the distribution of No. of Employees Assigned Films.

Figure 13

CALENDAR YEAR 1959

\section{SEX OF ANL EMPLOYEES EXPOSED TO EXTERNAL RADIATION - BODY FILM DATA}

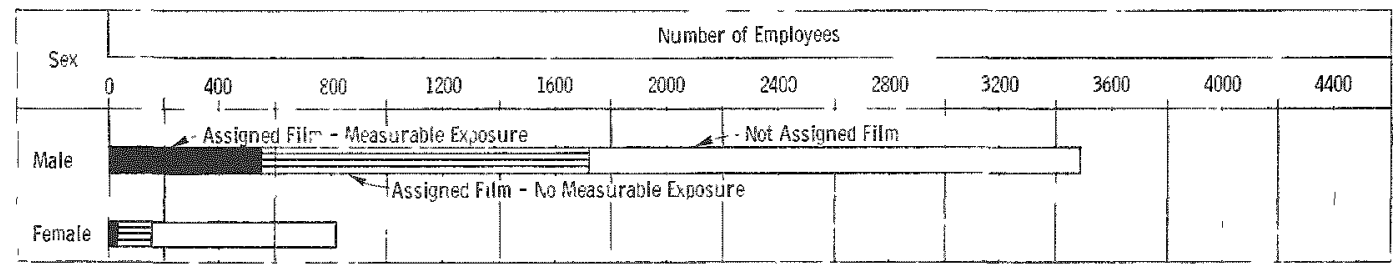

Table XVI

CAIENDAR YEAR 1960

SLK OF ANL EMPIOVEES EXPOSEO TO EXTERNAL RADIATION - BODY FILM DATA

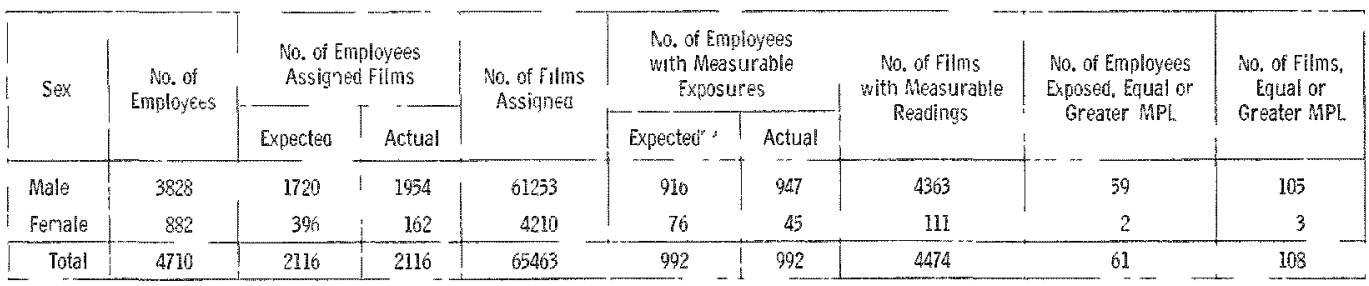

- Expected on the basis of distributing the number of film proportiopalv to the Job Group distribution.

"Expected on the bas is of distributing the No. of Emplovees with Measurable Readings proportionally to the distribution of No. of Employees Assigned Films.

Figure 14

CALENDAR YEAR 1960

\section{SEX OF ANL EMPLOYEES EXPOSED TO EXTERNAL RADIATION - BODY FILM DATA}

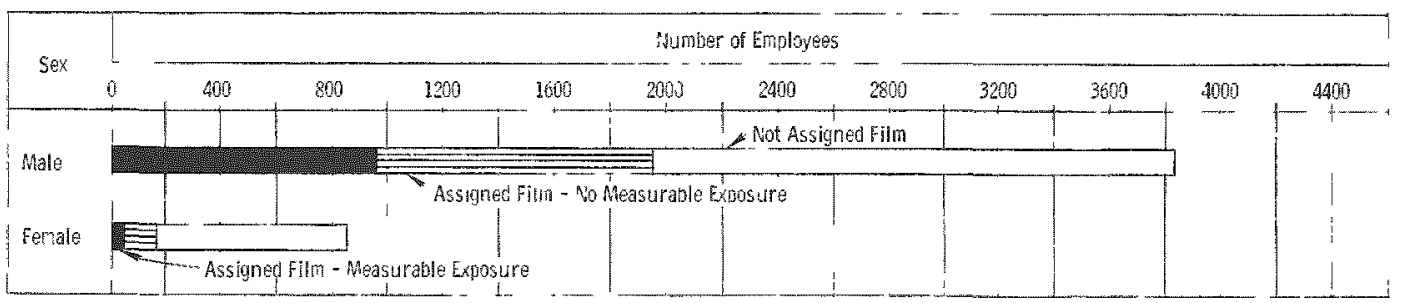


Table XVII

CALENDAR YEAR 1961

SEX OF ANL EMPLOYEES EXPOSED TO EXTERNAL RADIATION - BOOY FILM DATA

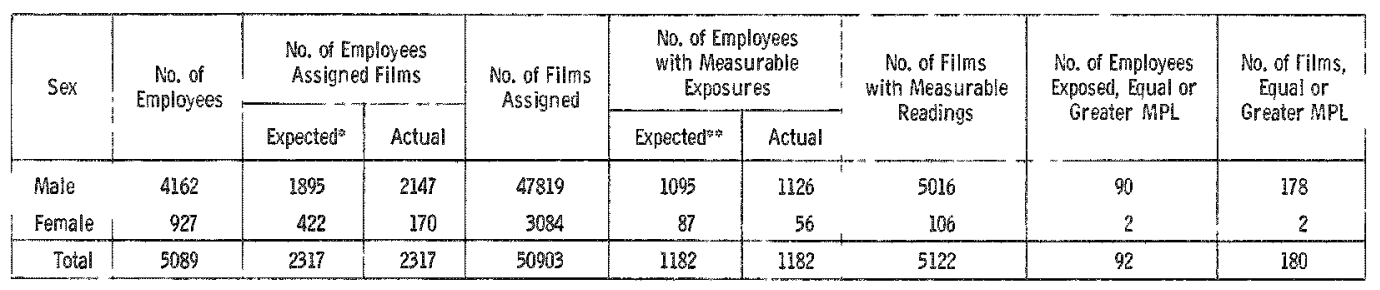

"Expected on the basis of distributing the number of film proportionally to the Job Group distribution.

*apected on the basis of distributing the No. of Employees with Measurable Readings proportionally to the distribution of Ho. of Employees Assigned Films.

Figure 15

CALENDAR YEAR 1961

SEX OF ANL EMPLOYEES EXPOSED TO EXTERNAL RADIATION - BODY FILM DATA

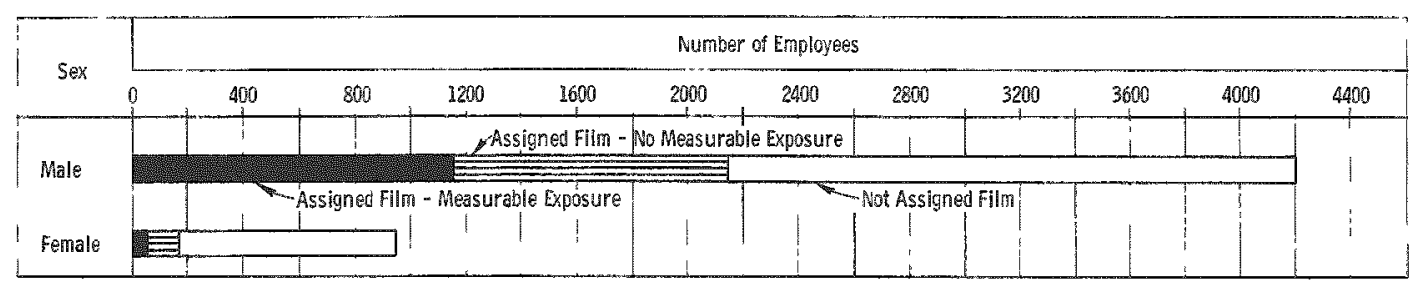

7. Distribution of Employees by Range of Exposure, Table XVIII

The distribution of employees by range of exposure shows very little change percentage-wise in the three years 1959-1961. The percentage of employees whose yearly accumulated exposures were less than the weekly MPL of $300 \mathrm{mr}$ was $88.4 \%$ in $1959,90.3 \%$ in 1960 and $88.8 \%$ in 1961. The yearly accumulated exposure for $99 \%$ of the employees in each of the three years was less than the quarterly MPL of $3.0 \mathrm{rem}$.

The highest accumulated exposure recorded in each year was $5.31 \mathrm{rem}$ in $1959,5.68 \mathrm{rem}$ in 1960 and $5.99 \mathrm{xem}$ in 1961.

The effect of changing to a two week monitoring period is seen in the slight increase in percentage of employees in each exposure range with the exception of the zero exposure range. The employees reported as having no measurable exposure decreased $8.0 \%$ from 1959-1961. 
Table XVIII

DISTRIBUTION OF EMPLOYEES BY RANGE OF EXPOSURE

\begin{tabular}{|c|c|c|c|c|c|c|c|c|c|}
\hline \multirow{2}{*}{$\begin{array}{l}\text { Exposure } \\
\text { Range, mr }\end{array}$} & \multicolumn{3}{|c|}{ Number of Employees } & \multicolumn{3}{|c|}{ Accumulated Totals } & \multicolumn{3}{|c|}{ Accumulated Percent } \\
\hline & 1959 & 1960 & 1961 & 1959 & 1960 & 1961 & 1959 & 1960 & 1961 \\
\hline 0 & 913 & 891 & 943 & 913 & 891 & 943 & 48.7 & 42.1 & 40.7 \\
\hline$I-99$ & 559 & 801 & 894 & 1472 & 1692 & 1837 & 78.5 & 79.9 & 79.3 \\
\hline $100-199$ & 119 & 163 & 157 & 1591 & 1855 & 1994 & 84.9 & 87.6 & 86.0 \\
\hline $200-299$ & 66 & 57 & 63 & 1657 & 1912 & 2057 & 88.4 & 90.3 & 88.8 \\
\hline $300-399$ & 41 & 33 & 39 & 1698 & 1945 & 2096 & 90.6 & 91.9 & 90.5 \\
\hline $400-499$ & 19 & 29 & 32 & 1717 & 1974 & 2128 & 91.6 & 93.3 & 91.8 \\
\hline $500-599$ & 19 & 24 & 30 & 1736 & 1998 & 2158 & 92.6 & 94.4 & 93.1 \\
\hline $600-699$ & 9 & 13 & 17 & 1745 & 2011 & 2175 & 93.1 & 95.0 & 93.9 \\
\hline $700-799$ & 8 & 13 & 11 & 1753 & 2024 & 2186 & 93.5 & 95.6 & 94.3 \\
\hline $800-899$ & 10 & 5 & 13 & 1763 & 2029 & 2199 & 94.1 & 95.9 & 94.9 \\
\hline $900-999$ & 7 & 6 & 11 & 1770 & 2035 & 2210 & 94.4 & 9.2 & 95.4 \\
\hline $1000-1499$ & 25 & 23 & 36 & 1795 & 2058 & 2246 & 95.8 & 97.2 & 96.9 \\
\hline $1500-1999$ & 20 & 18 & 25 & 1815 & 2076 & $227 \mathrm{I}$ & 96.8 & 98.1 & 98.0 \\
\hline $2000-2999$ & 36 & 24 & 23 & 1851 & 2100 & 2294 & 98.8 & 99.2 & 99.0 \\
\hline $3000-3999$ & 18 & 6 & 10 & 1869 & 2106 & 2304 & 99.7 & 99.5 & 99.4 \\
\hline $4000-4999$ & 4 & 8 & 8 & 1873 & 2114 & 2312 & 99.9 & 99.9 & 99.8 \\
\hline $5000-5999$ & 1 & 2 & 5 & 1874 & 2116 & 2317 & 100.0 & 100.0 & 100.0 \\
\hline
\end{tabular}

Figure 16

DISTRIBUTION OF EMPLOYEES

BY EXPOSURE - 1959
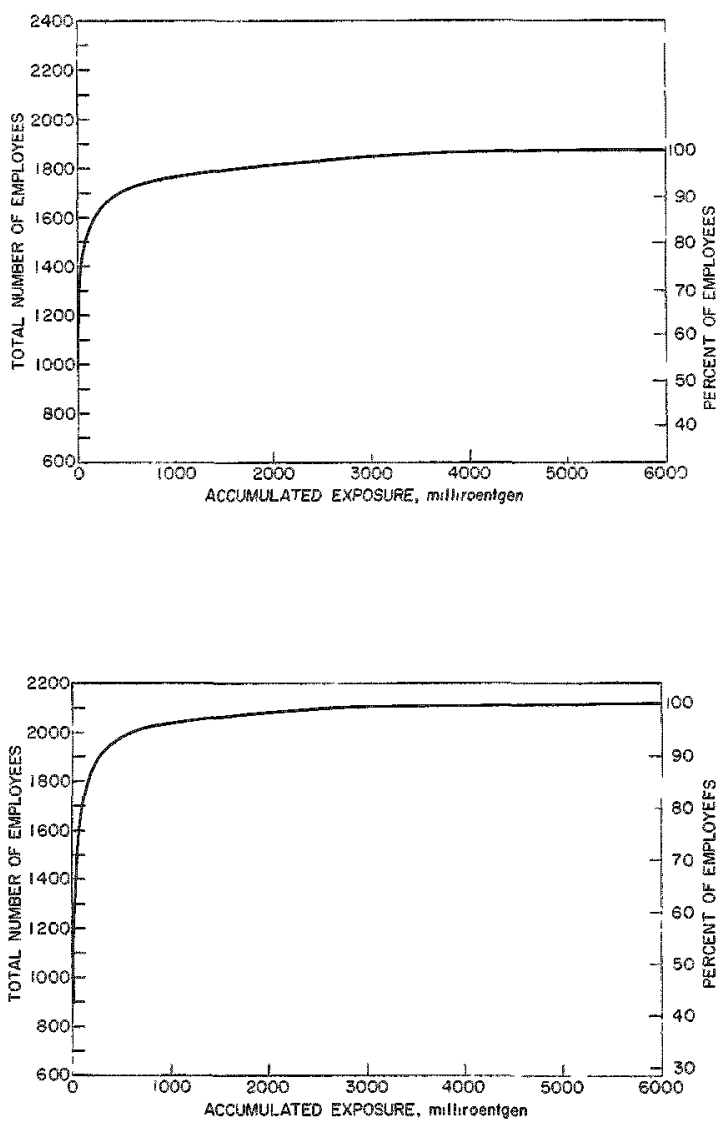

Figure 18

DISTRIBUTION OF EMPLOYEES

BY EXPOSURE - 1960

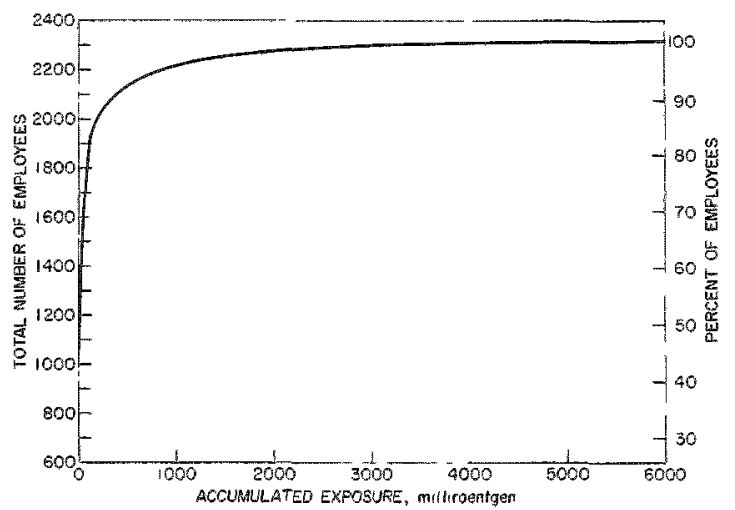

Figure 17

DISTRIBUTION OF EMPLOYEES BY EXPOSURE - 1961 
8. Evaluation of Performance - Indices of Exposure Experience, Table XIX

Figures 19-21 reveal that the Laboratory Radiation Safety program was quite effective from the third quarter of 1959 to the third quarter of 1960. The exposure rate was reduced $71.1 \%(1.82 \mathrm{mr} / \mathrm{hr})$ and the average exposure was reduced $42.4 \%(43.5 \mathrm{mr})$. Meanwhile, the frequency rate of exposures increased from the third quarter of 1959 to a peak in the first quarter of 1960 and then decreased to the third quarter of 1960. The frequency rate in the third quarter of 1960 still remained higher than in the third quarter of 1959. After the third quarter of 1960, the frequency rate is cyclic, but with a slight downward trend.

The change to the two-week monitoring period and more sensitive film occurred in the third quarter of 1960. Coincident with this change is a slight upward turn in both the exposure rate and the average exposure. The formula for determining the exposure rate is

$$
\begin{aligned}
& \Sigma \text { Readings in } \mathrm{mr} \text { of Each Film } \\
& \text { Exposure Rate }=\frac{\text { with a Measurable Reading }}{\begin{array}{l}
\text { No. Of Film with Measurable Readings } \mathrm{x} \\
\text { the Number of Hours Each Film Was Worn }
\end{array}} \text {. }
\end{aligned}
$$

From this it may be seen that in order for the exposure rate to increase, either the sum of the film readings must increase or the number of film with measurable exposures times the hours each film was worn must decrease.

This is particularly true since the frequency rate, which is determined as

$$
\text { Frequency Rate }=\frac{\begin{array}{l}
\text { Number of Films with Measurable } \\
\text { Readings } \geq 25 \mathrm{mr}
\end{array}}{\text { Total Manhours Worked by All Employees }} \times 10^{6}
$$

has shown a slightly downward trend. In order for the trend to be downward, the number of films with measurable readings must increase in proportionately greater numbers than the manhours worked. The distributions in Tables I-III show that the number of film with measurable readings increased from 1959 through 1961. The hours worn increased from 40 to $80 \mathrm{hr}$ beginning with the third quarter of 1960; therefore, the sum of the film readings had to increase also in order for the exposure rate to increase. Table XVIII shows that from 1960 through 1961 the number of persons receiving exposures increased in nearly every exposure interval. The same analogy will hold for the trend of the average exposures, where

$\Sigma$ Readings in $\mathrm{mr}$ of Each Film Average Exposure $=\frac{\text { with a Measurable Reading }}{\text { No. of Film with Measurable Readings } \geq 25 \mathrm{mr}} \cdot$ 
Table XIX

INDICES OF EXPOSURE EXPERIENCE

\begin{tabular}{|c|c|c|c|c|}
\hline $\begin{array}{c}\text { Calendar } \\
\text { Quarter }\end{array}$ & $\begin{array}{c}\text { Frequency } \\
\text { Rate }\end{array}$ & $\begin{array}{c}\text { Exposure } \\
\text { Rate, mr hr }\end{array}$ & $\begin{array}{c}\text { Average } \\
\text { Exposure, mr }\end{array}$ & $\begin{array}{c}\text { Number of Films with } \\
\text { Measurable Exposure }\end{array}$ \\
\hline $59-1$ & 398 & 2.36 & 94.3 & 779 \\
$59-2$ & 470 & 2.14 & 85.5 & 791 \\
$59-3$ & 506 & 2.56 & 102.5 & 866 \\
$59-4$ & 592 & 2.39 & 95.6 & 1049 \\
$60-1$ & 730 & 2.12 & 84.9 & 1348 \\
$60-2$ & 635 & 2.78 & 71.0 & 1168 \\
$60-3$ & 577 & 0.74 & 59.0 & 1063 \\
$60-4$ & 543 & 0.80 & 63.8 & 1129 \\
$61-1$ & 674 & 0.91 & 72.5 & 1245 \\
$61-2$ & 666 & 0.79 & 63.4 & 1485 \\
$61-3$ & 630 & 1.04 & 83.3 & 1178 \\
$61-4$ & 538 & 1.04 & 83.5 & 1227 \\
$62-1$ & 612 & 0.81 & 64.6 & 1232 \\
\hline
\end{tabular}

Figure 19

FREQUENCY RATE - NUMBER OF MEASURABLE EXPOSURES PER MILLION MANHOURS WORKED
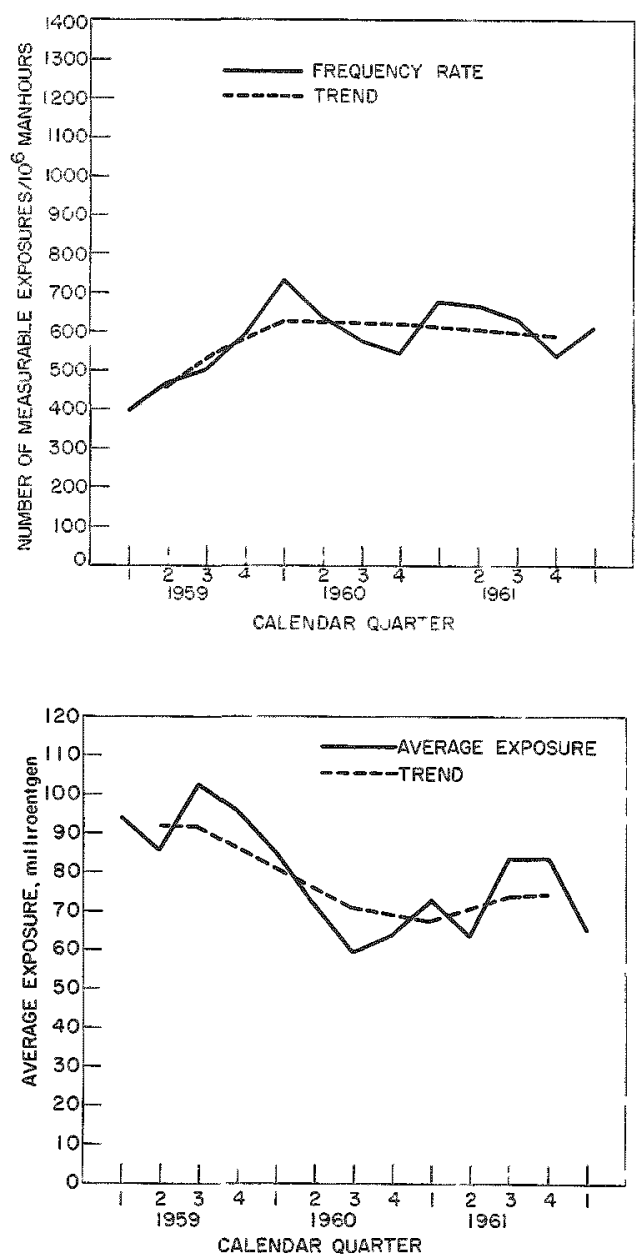

Figure 20

EXPOSURE RATE FOR FILM WITH MEASURABLE READINGS DETERMINED QUARTERL Y FOR 1959 THROUGH 1961 AND THE FIRST QUARTER 1962

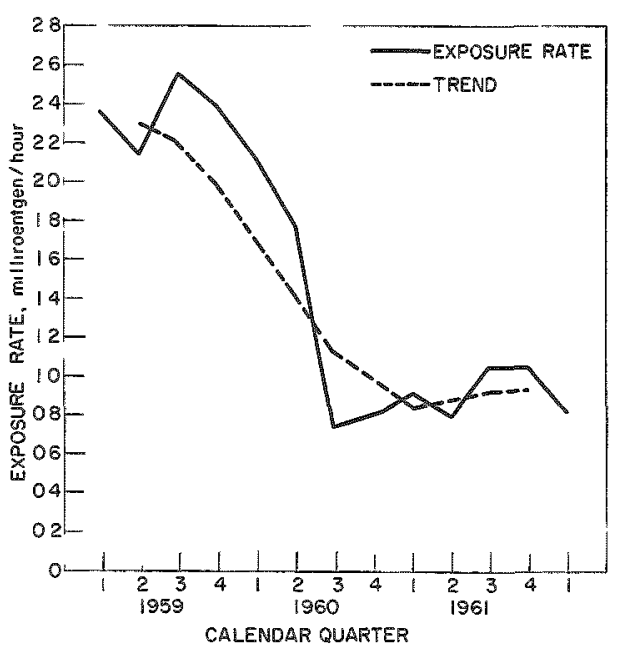

Figure 21

AVERAGE EXPOSURE FOR FILM WITH MEASURABLE READINGS DETERMINED QUARTERL F FOR 1959 THROUGH 1961 AND THE FIRST QUARTER 1962 


\section{E. CONCLUSIONS}

The combined data for the years 1959, 1960, and 1961 show that the average age of employees receiving measurable exposures is 35.5 years, with $95.45 \%$ of the employees in the age range from 17.5 to 55.5 years. However, the radiation safety policy of the Laboratory does not allow employees under the age of 18 to work in radiation areas; therefore, it is unlikely that an employee less than 18 years of age received any exposure to radiation.

The average age of employees that exceed the weekly MPL is 34.6 years, with $95.45 \%$ of the employees in the age range from 17 to 52 years.

The years 1960 and 1961 may be taken as being more representative of the exposure experience under the present dosimetry system. These years indicate the distribution of exposures to be approximately a normal distribution with regard to age. The mean age for each year is 35.6 years and the median age is 35.0 years.

The average years of employment for Laboratory employees re ceiving radiation exposures is 5.5 years over the three-year period. Since the average years of employment for all employees is 5.4 years, the years of employment for employees receiving exposures appears to be distributed about the same as that for the Laboratory population.

The most frequent exposures are incurred by groups of employees involved in reactor operations and maintenance, cyclotron operations and maintenance, and decontamination work. These groups also have the highest frequency of exposure in excess of maximum permissible levels.

The Scientific Staff and Technicians make up an average of $57.7 \%$ of the employees that receive measurable exposures. By the same token, they receive an average of $58.7 \%$ of the exposures. The Reactor Operators, on the other hand, do not have a large percentage of the total employees receiving exposures, but all of the operators receive exposures.

An increase in the number of exposures recorded occurred when the Laboratory changed from the one-week to the two-week monitoring period. The percentage of employees within a given exposure range has increased slightly。

The trend of the frequency of exposures is on a gradual decline. The trends of the exposure rate and average exposure were downward from the second quarter in 1959 through the first quarter in 1961. The trends changed to a slightly increasing exposure rate and average exposure beginning with the first quarter of 1961. Such results are an indication that the efforts to control radiation exposures to employees is improving in effectiveness. 


\section{APPENDIX A}

A. Groups Included in "Other Scientific":

1. Temporary Technical Employees

2. Physics Division

3. Biological and Medical Research Division

4. Reactor Drafting Section

5. Solid State Science Division

6. High Energy Physics Division

7. Particle Accelerator Division

8. International Institute of Nuclear Science and Engineering

9. Applied Mathematics Division

10. Radiological Physics Division

B. Groups Included in "Other Technical Services":

1. Electronics Division

2. Health Division

3. Special Materials Department

4. Technical Services Office

C. Groups Included in "Other Administrative and General Services":

1. Technical Information Division

2. Laboratory Director's Office

3. Business Manager's Office

4. Management Systems Department

5. ZGS Construction Management

6. Site Administration

7. Lodging and Food Services

8. Security Division (other than Plant Protection)

9. Graphic Arts Department

10. Legal Department

11. Accounting Department

12. Materials Handling Department

13. Purchasing Department

14. Personnel Department

15. Plant Engineering Division

16. Idaho Branch Administration 


\section{REFERENCE}

1. J.F.Ege, Jr., IONIZING RADIATION, 4th Edition Accident Prevention Manual For Industrial Operations, Chapter 43, p. 38: National Safety Council, Chicago 11, Illinois (1959).

\section{ACKNOWLEDGEMENT}

A report such as this one was first suggested by Evelyn Hall Parent in March 1958. The format of the tables were established by her in a pilot report which she produced in her early work.

The program for the IBM-1401 and IBM-704 computer was written by Megumu Yoshimine of the Applied Mathematics Division.

The author wishes to thank J.F.Ege, Jr, J.R. Novak, D, P O'Neil, R. V. Wheeler, J. H. Pingel, and A, G. Januska for reviewing the report and offering their comments, suggestions, and encouragement. 